\title{
Characterization of the subcellular localization of Epstein-Barr virus encoded proteins in live cells
}

\author{
Mingsheng Cai ${ }^{2}$, Zongmin Liao ${ }^{2}$, Tao Chen ${ }^{2}$, Ping Wang ${ }^{2}$, Xingmei Zou' ${ }^{2}$ Yuanfang \\ Wang $^{2}$, Zuo Xu ${ }^{2}$, Si Jiang ${ }^{2}$, Jinlu Huang ${ }^{3}$, Daixiong Chen², Tao Peng ${ }^{2}$, Gengde Hong ${ }^{4}$ \\ and Meili Li ${ }^{1,2}$ \\ ${ }^{1}$ Guangdong Provincial Key Laboratory of Allergy and Clinical Immunology, Second Affiliated Hospital of Guangzhou Medical \\ University, Guangzhou 510260, Guangdong, China \\ ${ }^{2}$ Department of Pathogenic Biology and Immunology, Sino-French Hoffmann Institute, School of Basic Medical Science, \\ Guangzhou Medical University, Guangzhou 511436, Guangdong, China \\ ${ }^{3}$ Guangdong Haid Group Co., Ltd., Guangzhou 511400, Guandong, China \\ ${ }^{4}$ The Third Clinical School of Guangzhou Medical University, Guangzhou 510150, Guangdong, China \\ Correspondence to: Meili Li, email: meili_2011@hotmail.com
}

Keywords: Epstein-Barr virus, subcellular localization, live cell microscopy

Received: February 03, 2017

Accepted: June 29, 2017

Published: July 25, 2017

Copyright: Cai et al. This is an open-access article distributed under the terms of the Creative Commons Attribution License 3.0 ( $C C$ BY 3.0), which permits unrestricted use, distribution, and reproduction in any medium, provided the original author and source are credited.

\section{ABSTRACT}

Epstein-Barr virus (EBV) is the pathogenic factor of numerous human tumors, yet certain of its encoded proteins have not been studied. As a first step for functional identification, we presented the construction of a library of expression constructs for most of the EBV encoded proteins and an explicit subcellular localization map of 81 proteins encoded by EBV in mammalian cells. Viral open reading frames were fused with enhanced yellow fluorescent protein (EYFP) tag in eukaryotic expression plasmid then expressed in COS-7 live cells, and protein localizations were observed by fluorescence microscopy. As results, $34.57 \%$ ( 28 proteins) of all proteins showed pan-nuclear or subnuclear localization, 39.51\% (32 proteins) exhibitted pancytoplasmic or subcytoplasmic localization, and $25.93 \%$ ( 21 proteins) were found in both the nucleus and cytoplasm. Interestingly, most envelope proteins presented pancytoplasmic or membranous localization, and most capsid proteins displayed enriched or complete localization in the nucleus, indicating that the subcellular localization of specific proteins are associated with their roles during viral replication. Taken together, the subcellular localization map of EBV proteins in live cells may lay the foundation for further illustrating the functions of EBV-encoded genes in human diseases especially in its relevant tumors.

\section{INTRODUCTION}

Epstein-Barr virus (EBV), a representative member of family gammaherpesvirus (large DNA virus) that can afford interesting model system for viral-host interactions, is related with some severe human health problems such as infectious mononucleosis, various malignancies including nasopharyngeal carcinoma (NPC), gastric carcinoma, diffuse large B-cell lymphoma, NK/T-cell lymphomas, as well as Hodgkin Lymphoma (HL), Burkitt Lymphoma
(BL) and post-transplant lymphoproliferative disease (PTLD) [1-3]. The EBV genome is composed of linear double-stranded DNA, about 172 kilobase pairs (kb) in length. Until now, it is reported that EBV encodes approximately 80 to 86 proteins (depending on the strain) [4-7], among which at least 33 are structural components of the virion [8]. However, the absolute number of EBVencoded proteins is still under investigation because of the examination of different gene transcript products in varied types of infected cells [4, 7, 9-14]. In terms of 
their localization in the virions, the proteins could be divided into five groups: envelope, tegument, capsid, and unclassified and nonstructural proteins. This complicated network of proteins leads to various consequences on the host cell and guarantees efficient proliferation of the virus.

Although the features of a set of these proteins are already well studied, there is little or nothing report concerning the role of many of the proteins. Therefore, more exhaustive analyses might contribute to figure out the complexity of the EBV pathogenic repertoire. A better perceiving of the individual protein functions is not only conducive to establish the complex replication and potentially approaches for inhibition of propagation, but also helpful for revealing the mechanisms that manipulate vital cellular processes by EBV. Subcellular localization of a protein reflects and is closely correlated with its function, and establishment of the subcellular localization has been demonstrated to be a helpful fashion to estimate the potential functions of a great number of proteins [15], where individual proteins were expressed fused to epitope or to GFP tags [16, 17]. For most proteins, localization results were disclosed to be consistent in different survey regardless of the tag used or expression level. Subcellular localization screening is also a proper starting point to identify the roles of a certain protein of herpesvirus, giving insight into the potential effect of the protein in the course of infection, as well as the cellular processes that may be regulated.

The subcellular localization of part of the EBVencoded proteins is not known yet. To acquire a more comprehensive knowledge of the functions of EBV proteins, we constructed a mammalian expression library that is composed of most of the open reading frames (ORFs) of EBV. These proteins fused to the $\mathrm{C}$ terminus of enhanced yellow fluorescent protein (EYFP) tag that reasonable for protein localization exploration were expressed in COS-7 live cells, and we presented the subcellular localization for all of these EBV-encoded proteins.

\section{RESULTS}

As a substantial step to figure out the detailed function of EBV-encoded proteins, a research has been performed to establish the genome-wide subcellular localization map of EBV-encoded proteins. To investigate the subcellular localization, almost each of the predicted ORFs from EBV, were isolated, and inserted into the expression plasmid, in frame fused with the $\mathrm{C}$ terminus of a $27 \mathrm{kDa}$ EYFP tag-encoding sequence, which is demonstrated may but not exert significant influences on protein subcellular localization and favourable for direct fluorescence detection of the respective proteins in live cells. The constructed plasmids were confirmed and transfected into COS-7 cells for expression. COS-
7 cells were used as a cell system for these studies because they exhibit a larger cytoplasm than HEK293 cells, which are the more commonly utilized cell types for subcellular localization study. Furthermore, the subcellular localizations of some representative EBV proteins fused with Flag tag were also detected using indirect immunofluorescence (IFA), to make the data more convincing. To get a general overview of the subcellular localization of each protein, Zeiss Axiovert $200 \mathrm{M}$ microscope was employed. With this procedure the EBV proteins could be clearly observed in considerable transfected cells. Although not every potential ORF was recovered in the high through-put cloning effort, we produced expression constructs for the majority of EBV, namely 81 EBV ORFs. Among these EBV ORFs, 78 were cloned from B95-8 strain of EBV (174-kb BAC), and the rest ORFs ( $L F 1, L F 2$ and $L F 3)$, which could not isolate from 174-kb BAC, were cloned from the BAC DNA of EBV Akata strain of EBV (AK-BAC).

Protein localizations were broadly classified as pan-cellular (means protein diffusely localized throughout the cytoplasm and nucleoplasm), pan-cytoplasmic (means protein diffusely localized through-out the cytoplasm) or subcytoplasmic (means protein can form spots or concentrated at some subcellular organelles in the cytoplasm), pan-nuclear (means protein diffusely localized through-out the nucleoplasm) or subnuclear (means protein can form spots or concentrated at some subcellular organelles in the nucleus). Some proteins possess more complicated localization patterns and can be divided into multiple categories and, in these cases, the protein was presented in the most prevailing category, since they certainly have the capability to form subcellular structures in some instances, perhaps at higher expression levels. A comprehensive list of all proteins expressed in this study are summarized in Figures 1 to 4 and detailed in Tables 1 to 3 . In terms of their localizations, the EBV-encoded proteins could be generally fell into three groups: 28 proteins (34.57\%) with nuclear or subnuclear localization (Figure 1 and Table 1), 32 proteins (39.51\%) with cytoplasmic or subcytoplasmic localization (pancytoplasmic) (Figure 2 and Table 2), and 21 proteins $(25.93 \%)$ were localized in both the cytoplasm and the nucleus (pan-cellular) (Figure 3 and Table 3). As a control, the fluorescence of EYFP from cells transfected with pEYFP-C1 was presented evenly distributed throughout the cytoplasm and the nucleoplasm but not the nucleolar structures (Figure 1).

Of the 81 viral proteins we tested, $20 \mathrm{EBV}$ proteins have not been previously characterized with respect to their localization and most of these proteins also lack any functional identification, 52 EBV proteins have previously published subcellular localization data, and these results are in consonance with previous reports (see Tables 1 to 3 for individual protein results). Meanwhile, 

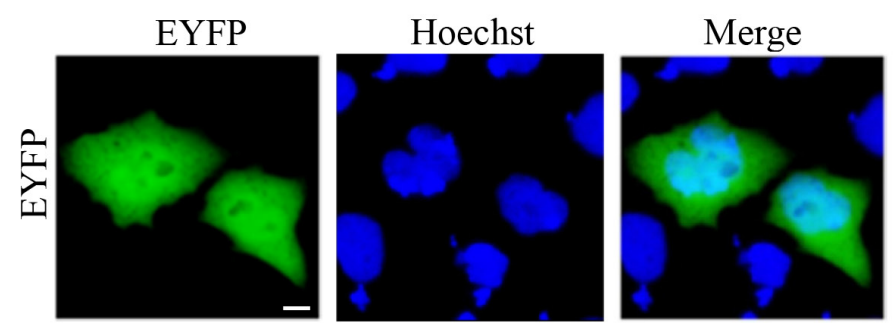

Transmitted
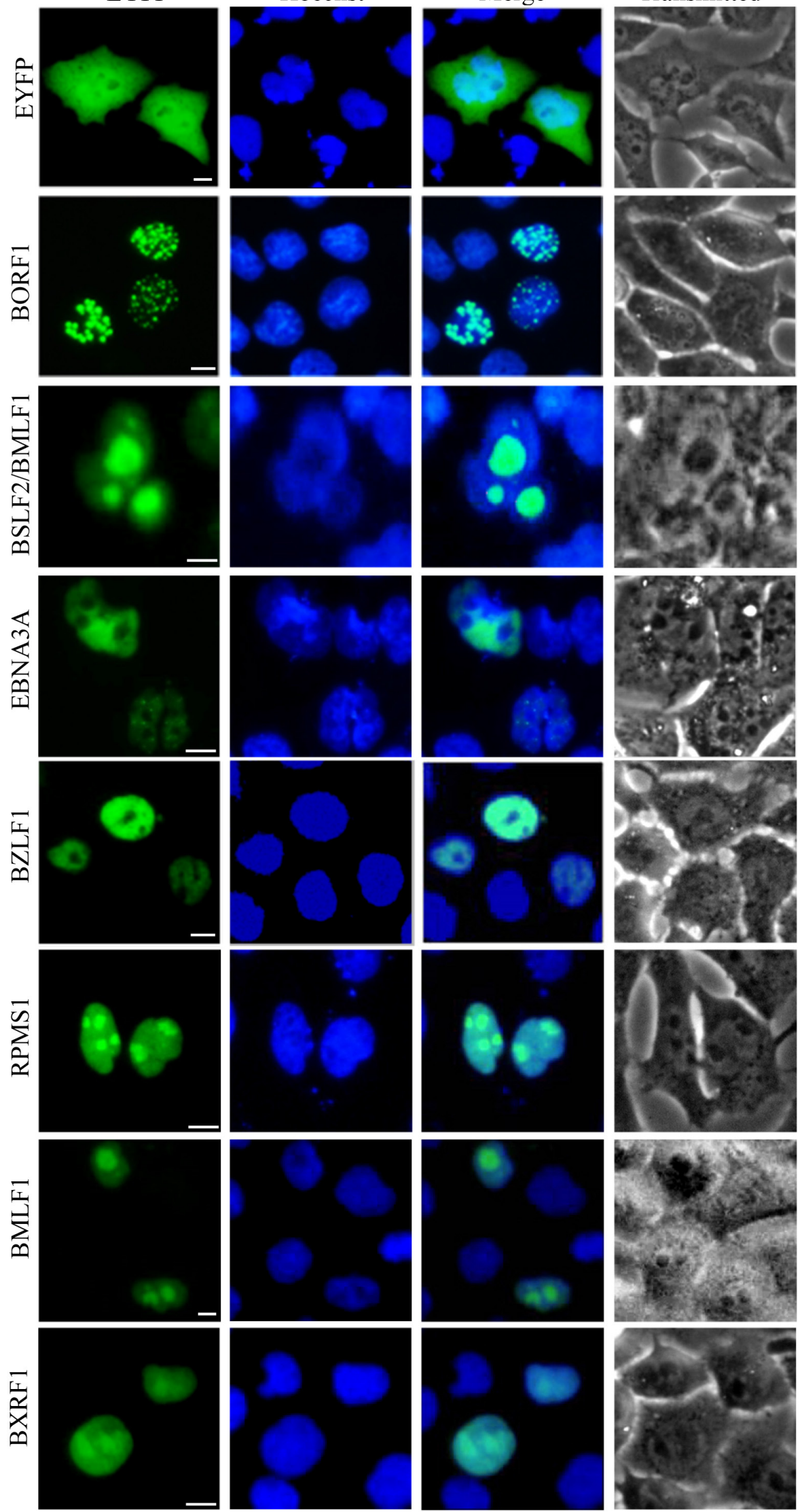

(Continued) 


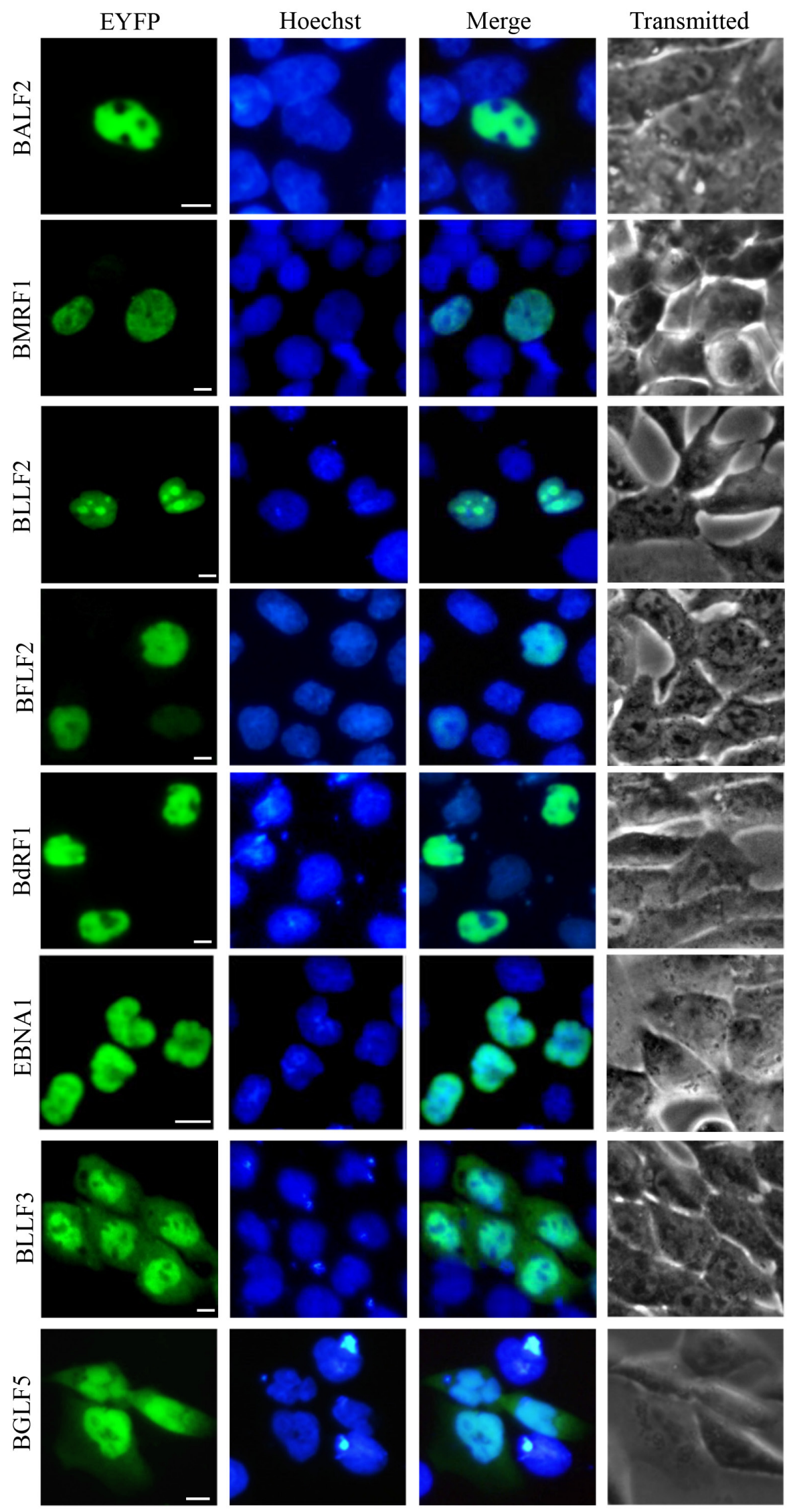

(Continued) 

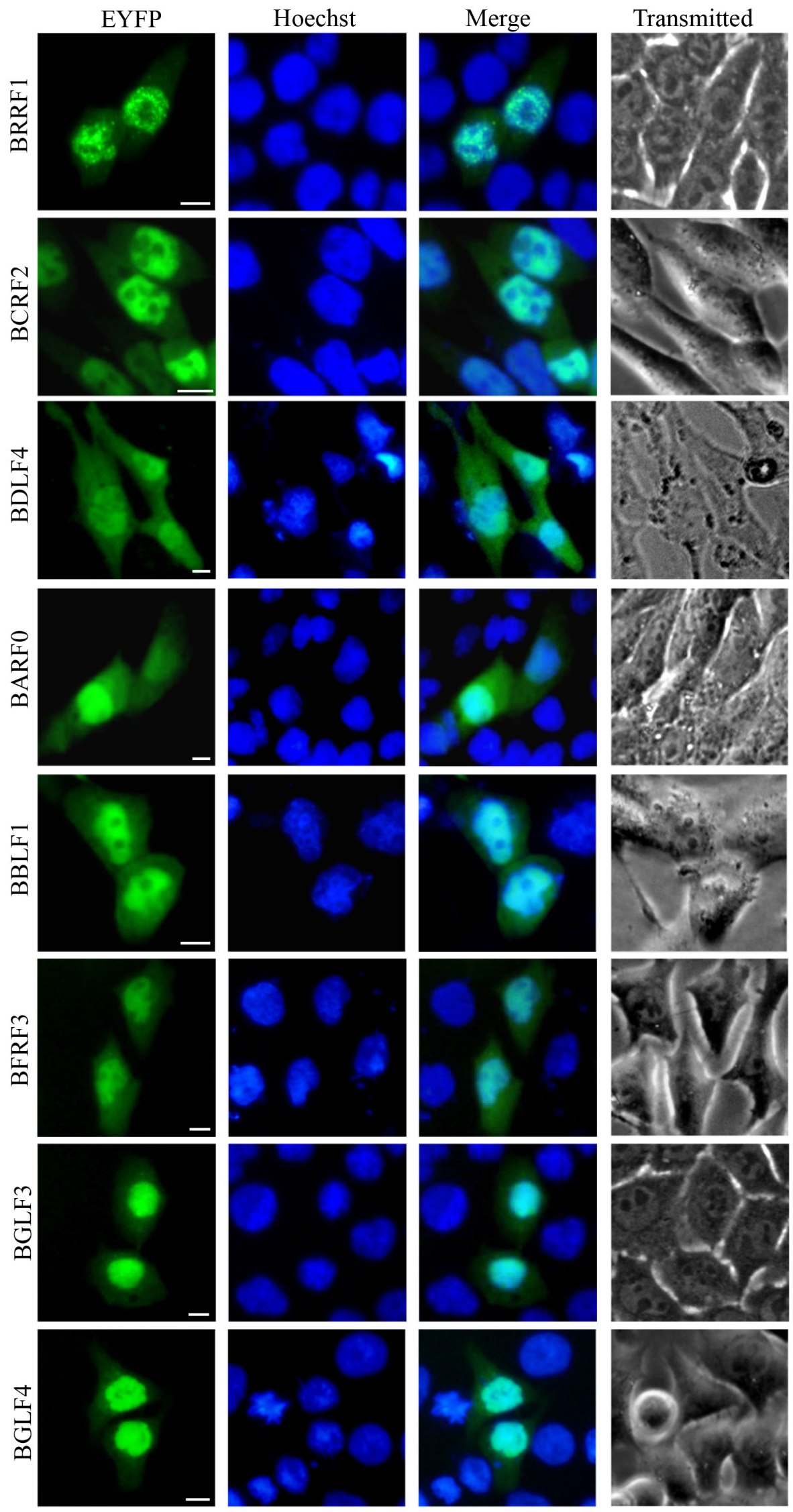

(Continued) 

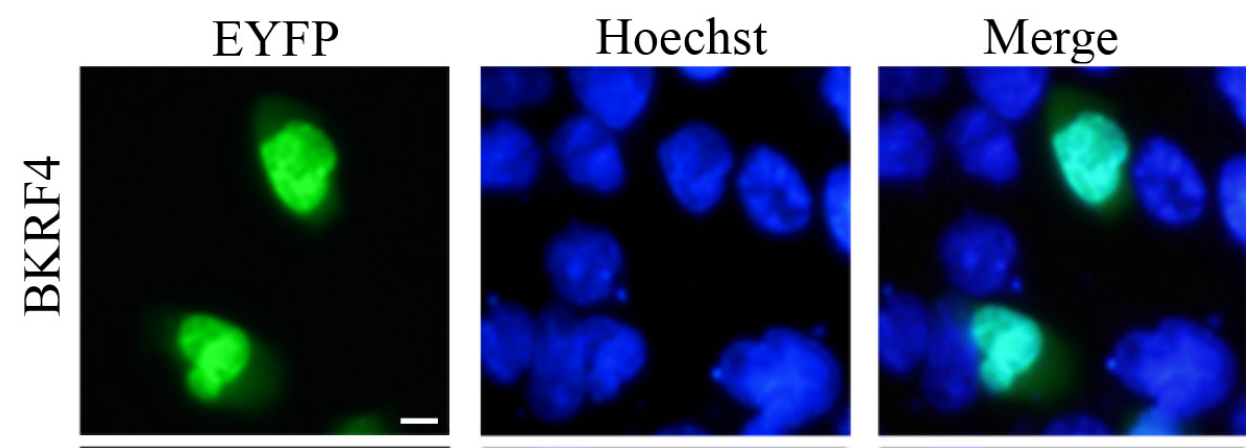

\section{Transmitted}
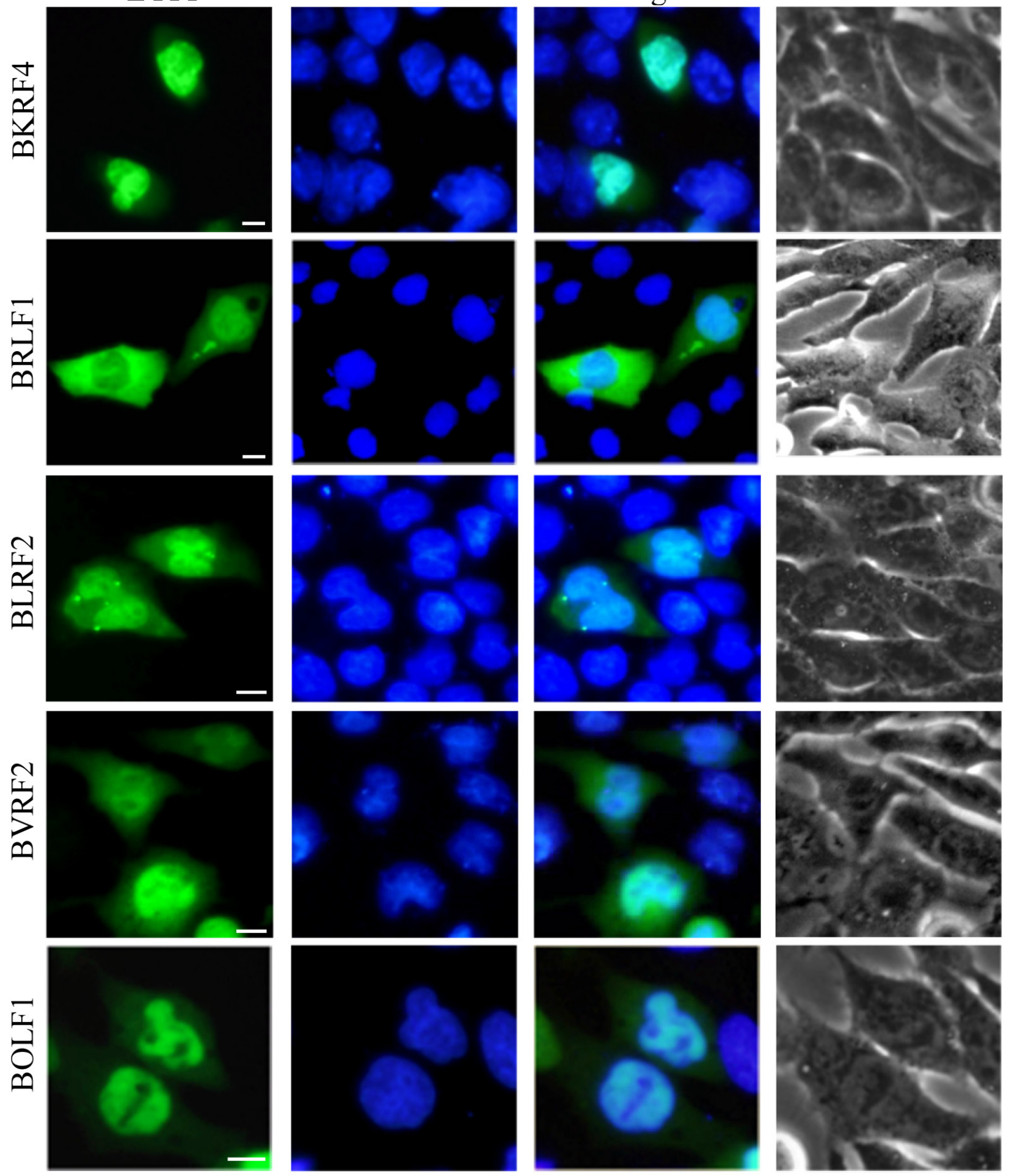

Figure 1: Nuclear localization summary of EBV-encoded proteins. 28 EYFP-fused EBV proteins were expressed in COS-7 cells, and cells were subjected to fluorescence microscope analysis in live cells $24 \mathrm{~h}$ after transfection. As a negative control, cells were transfected with the vector control (pEYFP-C1). Pictures were obtained using a Zeiss Axiovert 200M microscope. The same magnification was used in all panels. Representative fluorescence images of the vast majority live cells expressing indicated fusion protein were shown. Cells were counterstained with Hoechst to visualize the nuclear DNA. All scale bars indicate $10 \mu \mathrm{m}$. 

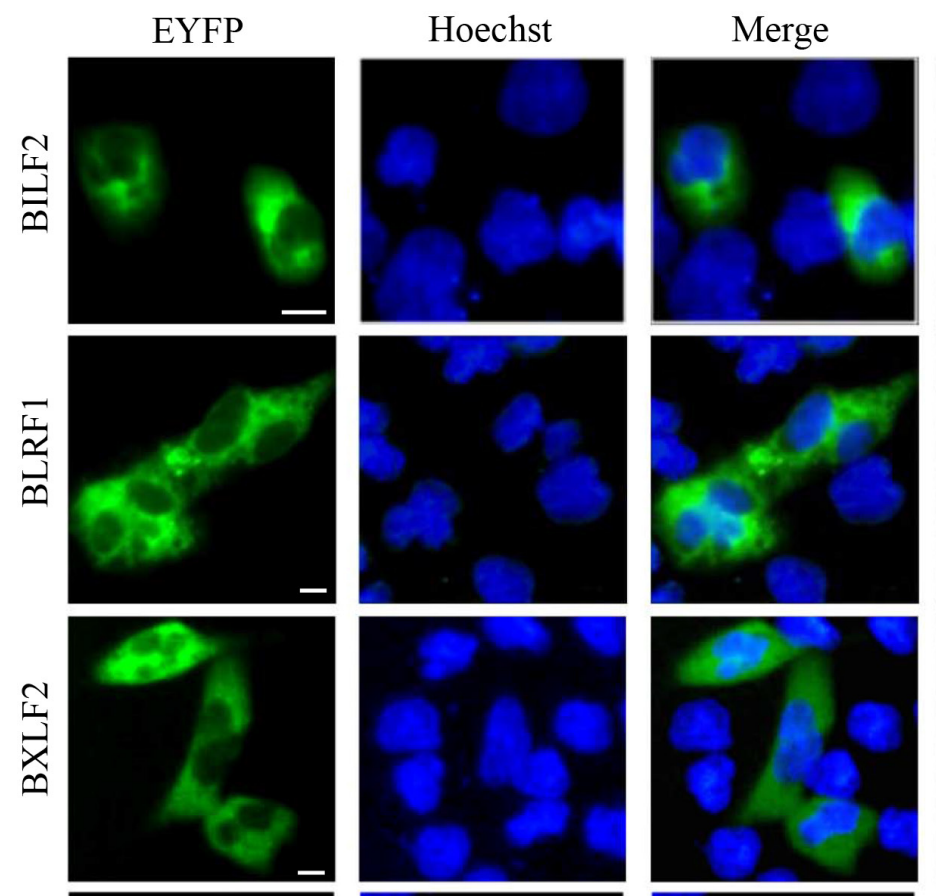

Transmitted
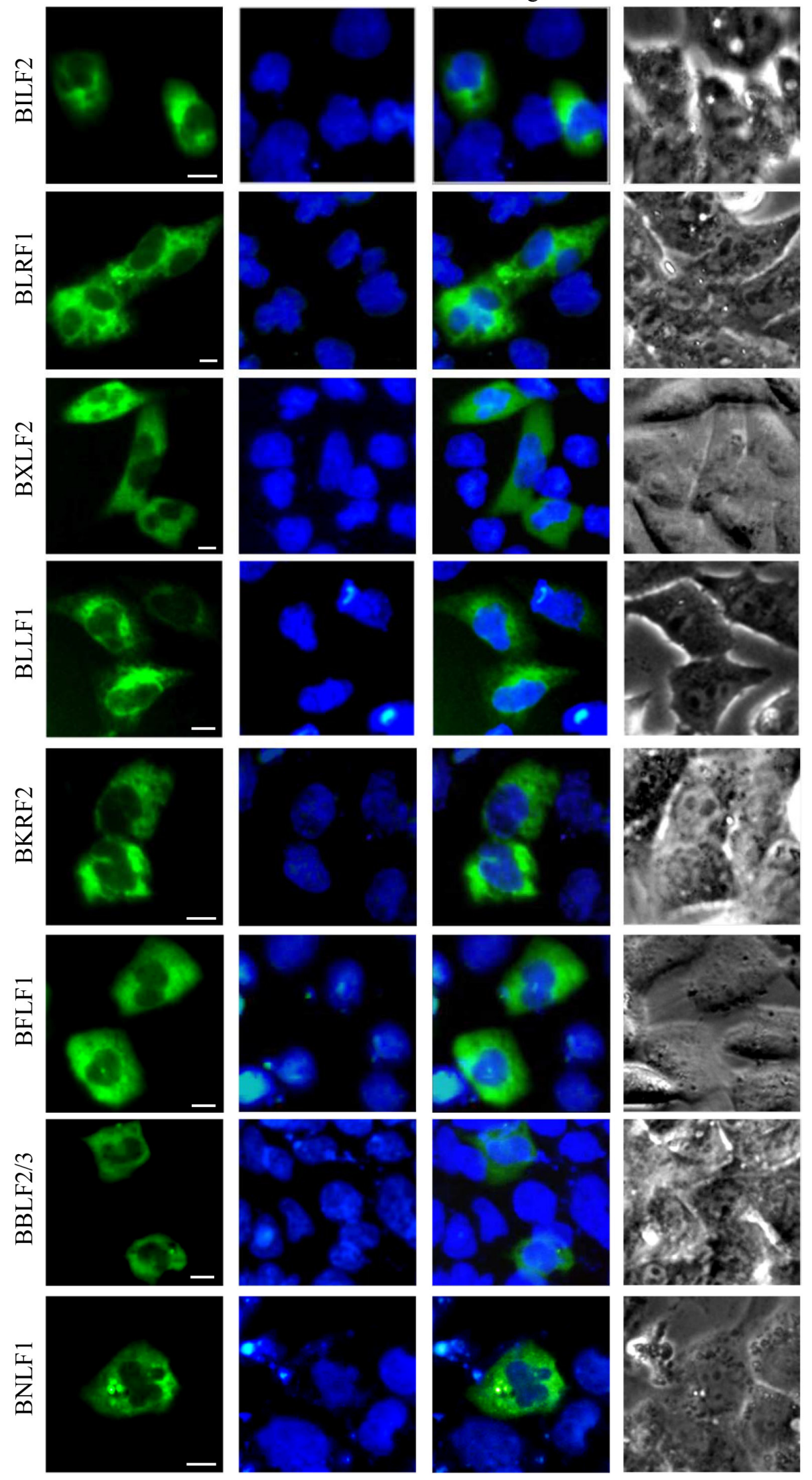

(Continued) 

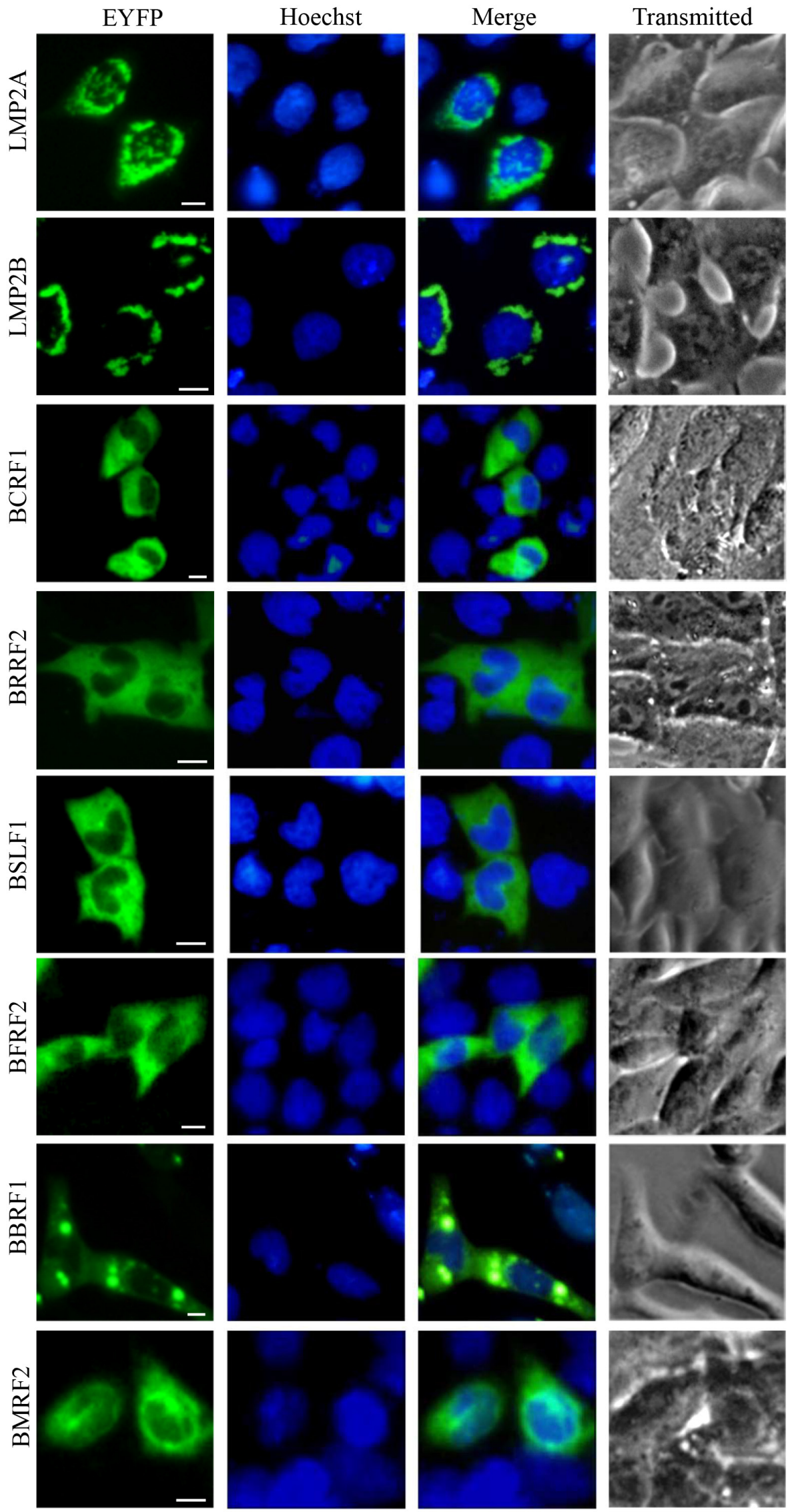

(Continued) 


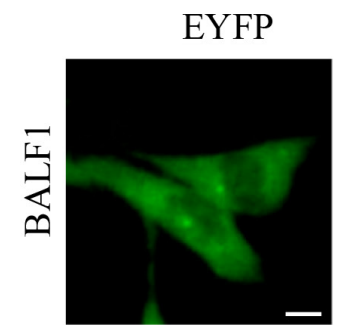

Hoechst

Merge

Transmitted
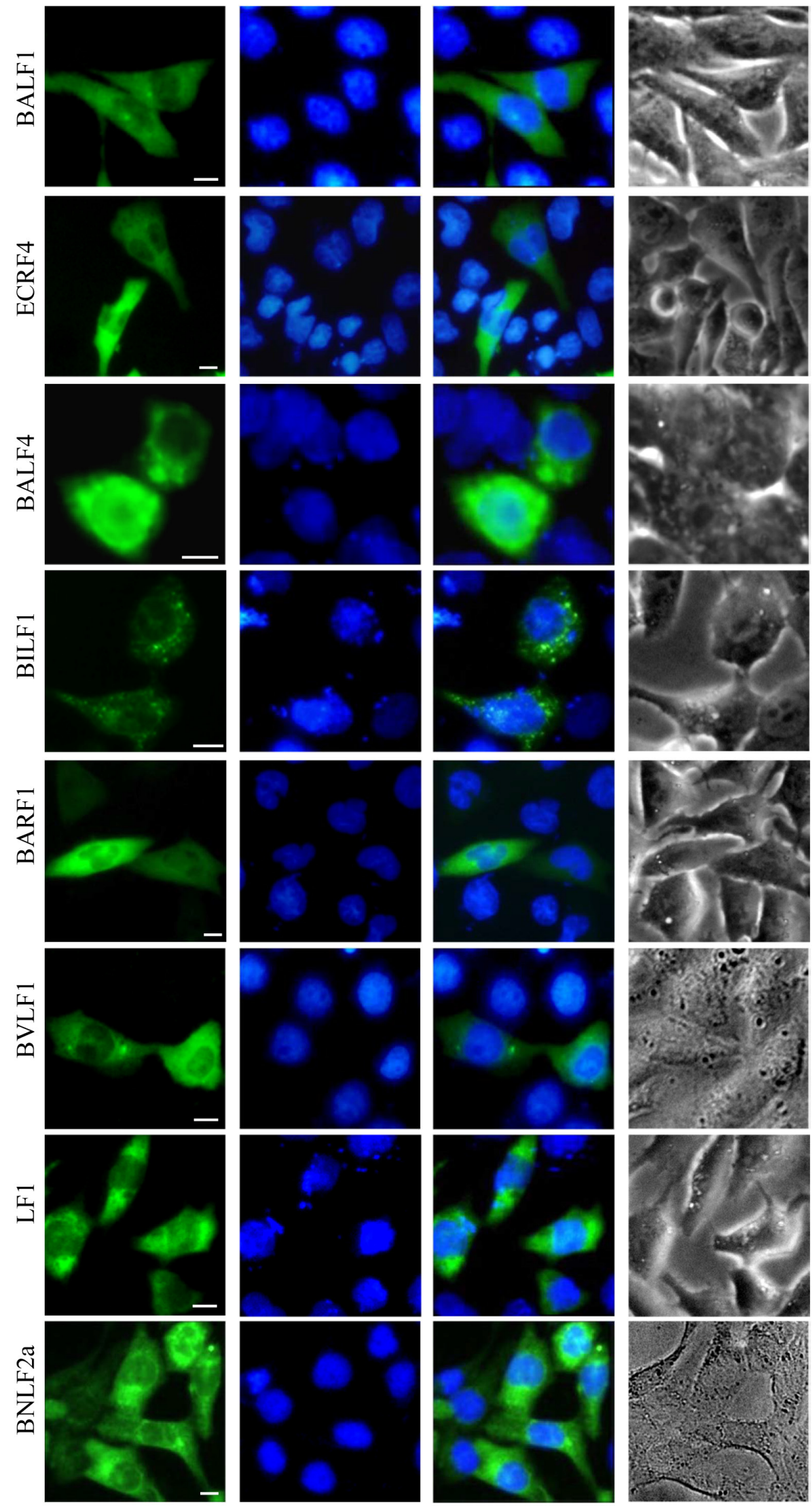

(Continued) 

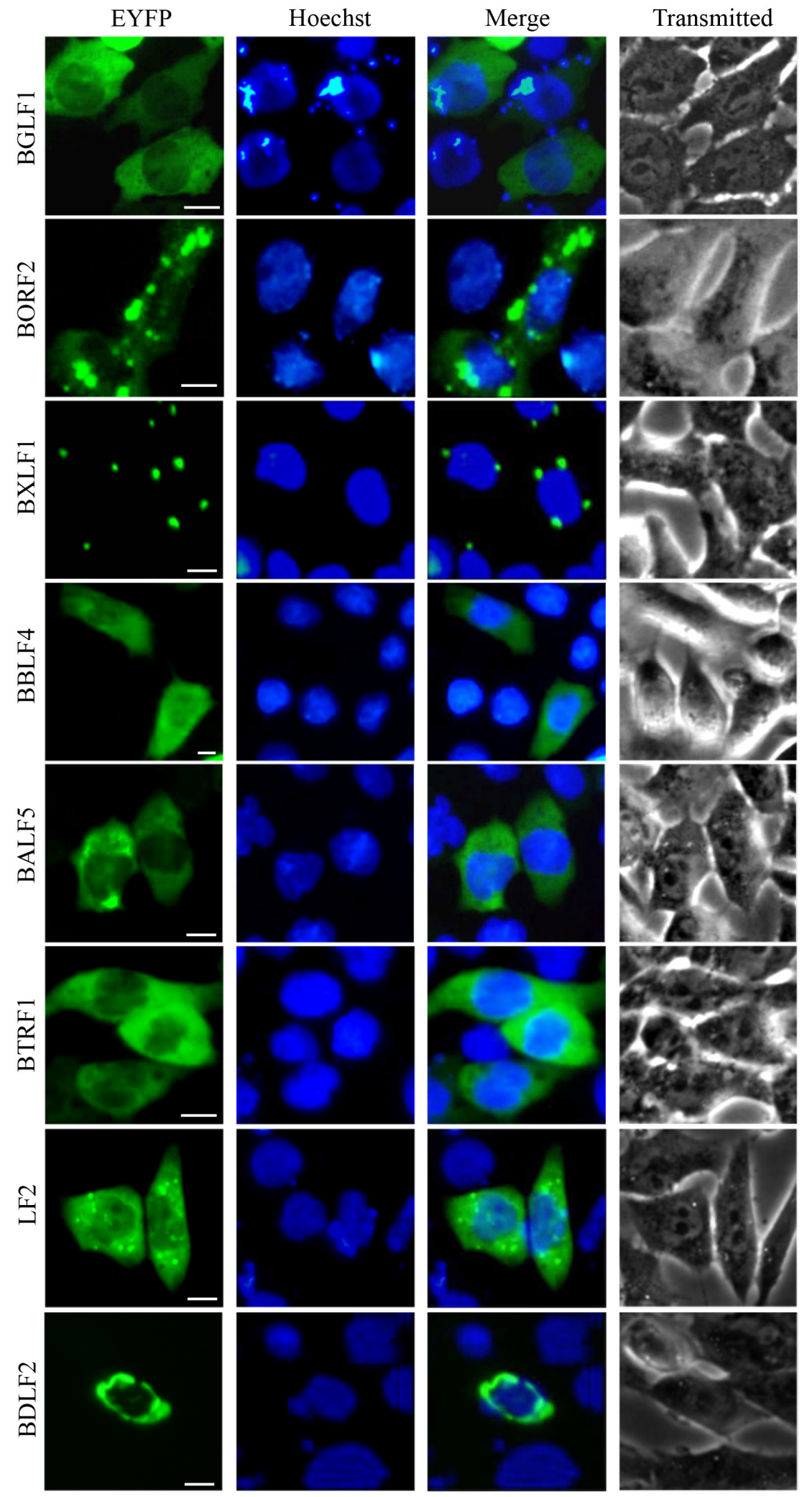

Figure 2: Cytoplasmic localization summary of EBV-encoded proteins. 32 EYFP-fused EBV-encoded proteins were expressed in COS-7 cells, and cells were subjected to fluorescence microscope analysis in live cells $24 \mathrm{~h}$ after transfection. Pictures were obtained using a Zeiss Axiovert 200M microscope. The same magnification was used in all panels. Representative fluorescence images of the vast majority live cells expressing indicated fusion protein were shown. Cells were counterstained with Hoechst to visualize the nuclear DNA. All scale bars indicate $10 \mu \mathrm{m}$. 

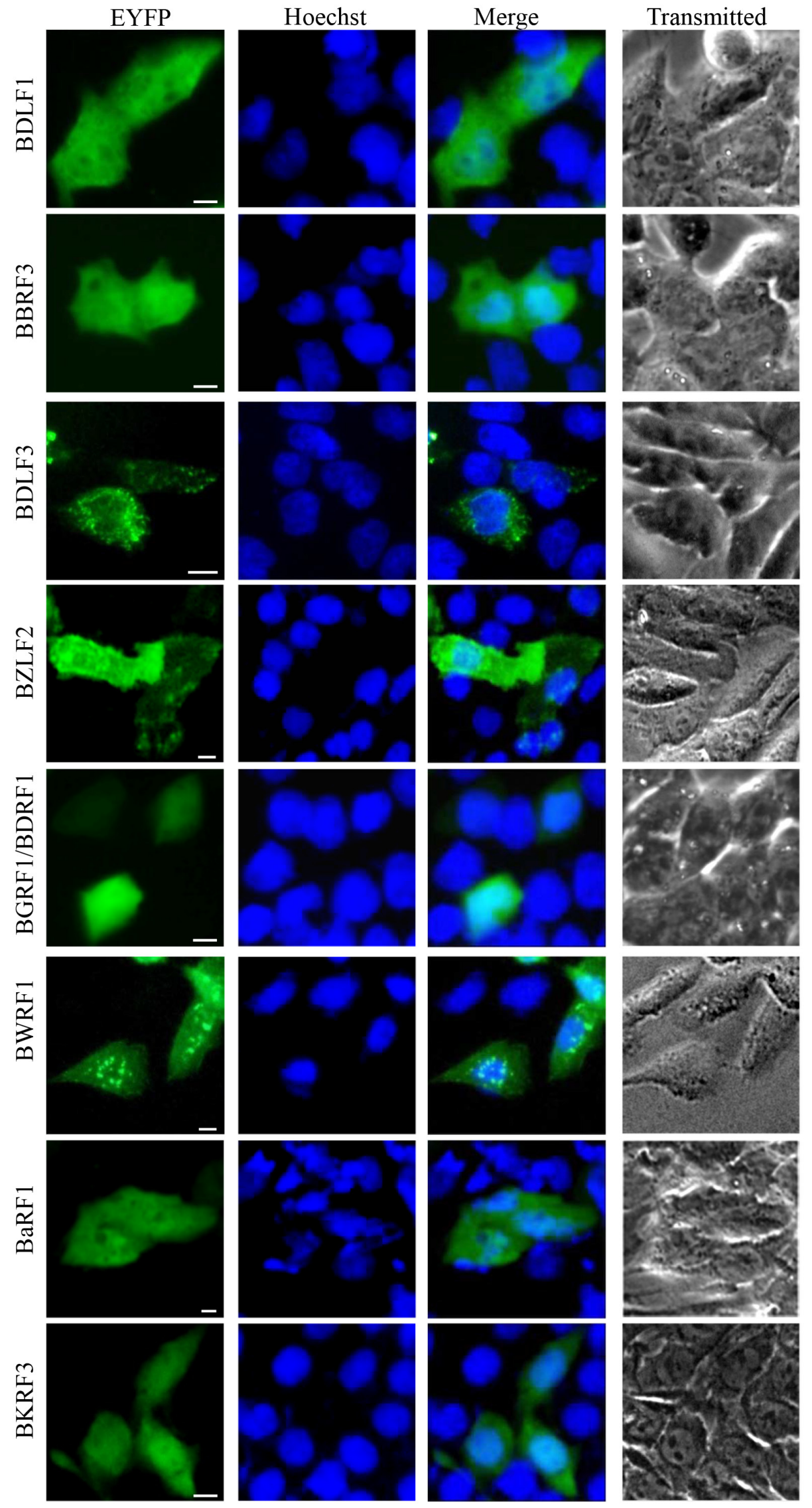

(Continued) 

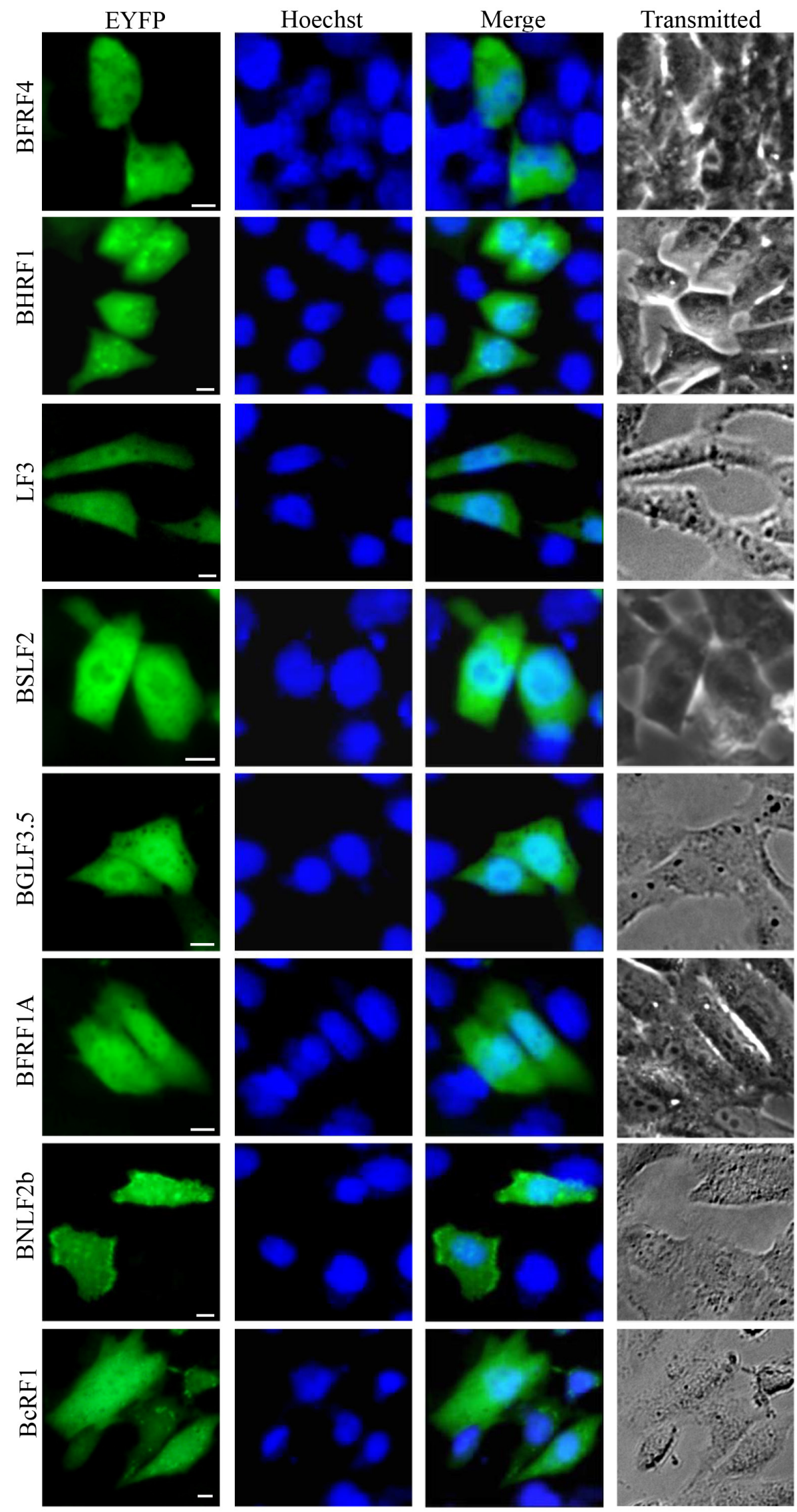

(Continued) 

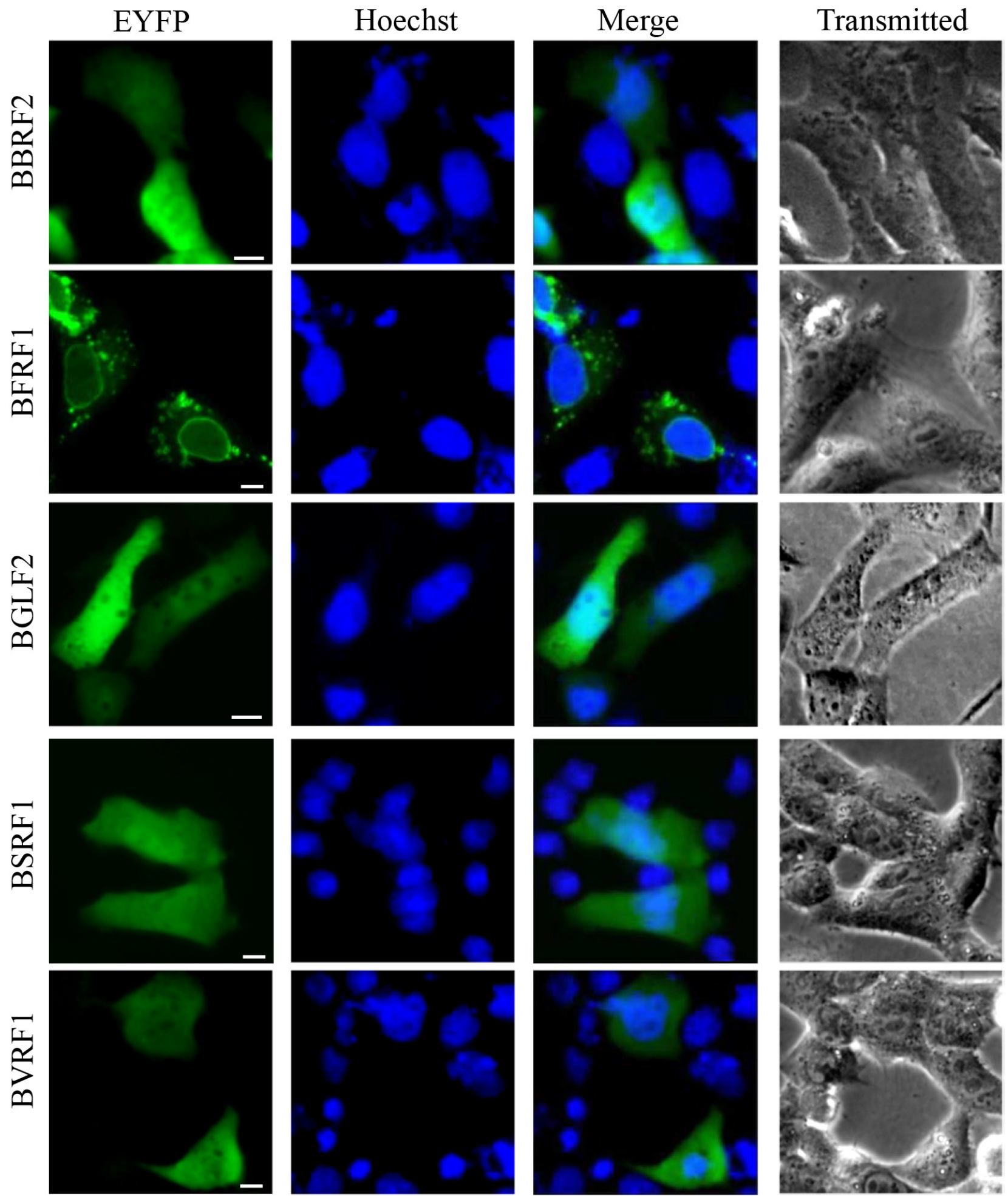

Figure 3: Pan-cellular localization summary of EBV-encoded proteins. 21 EYFP-fused EBV proteins were expressed in COS-7 cells, and cells were subjected to fluorescence microscope analysis in live cells $24 \mathrm{~h}$ after transfection. Pictures were obtained using a Zeiss Axiovert 200M microscope. The same magnification was used in all panels. Representative fluorescence images of the vast majority live cells expressing indicated fusion protein were shown. Cells were counterstained with Hoechst to visualize the nuclear DNA. All scale bars indicate $10 \mu \mathrm{m}$. 
A
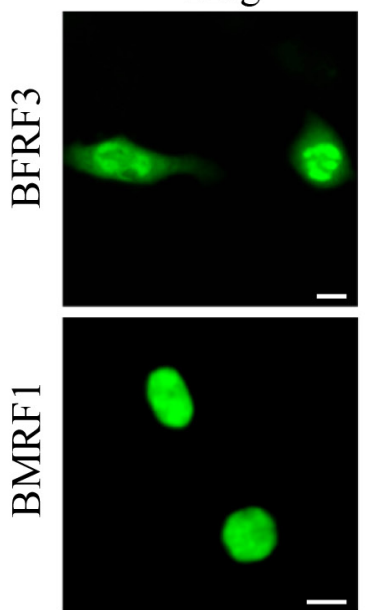

B
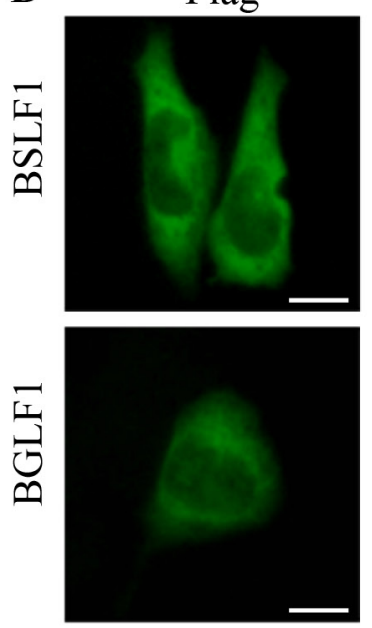

C
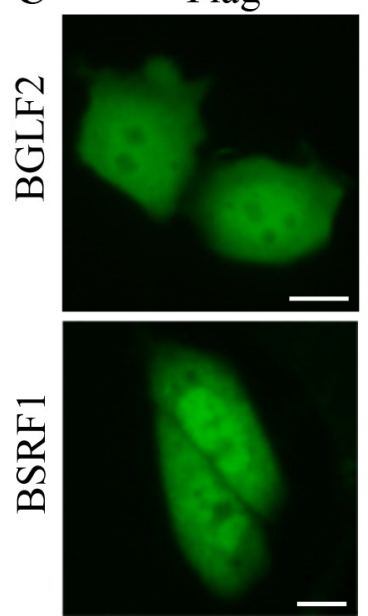

Hoechst
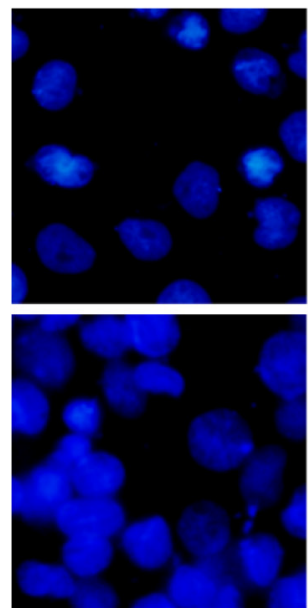

Hoechst
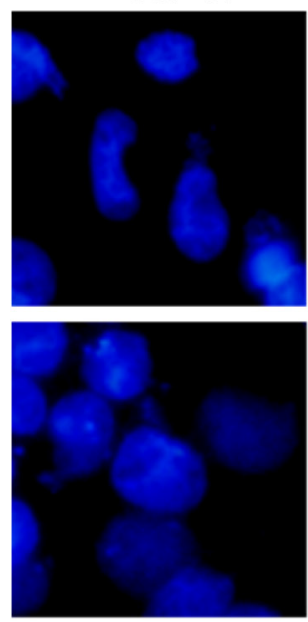

Hoechst
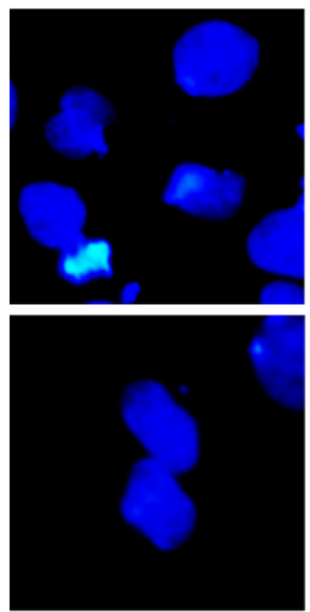

Merge
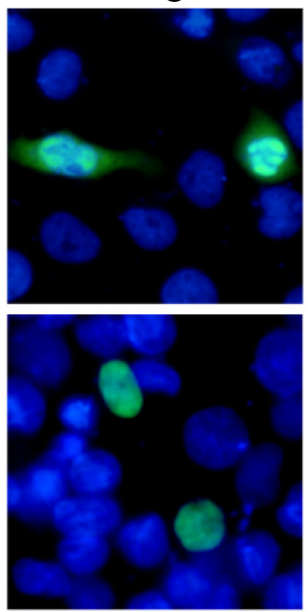

Merge
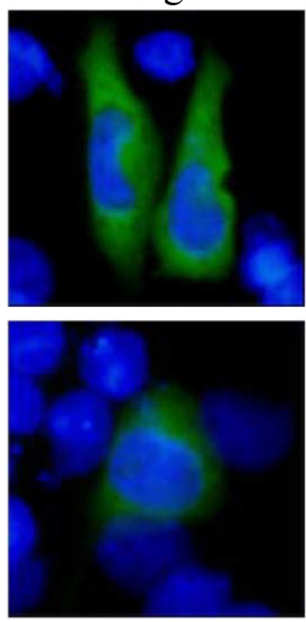

Merge
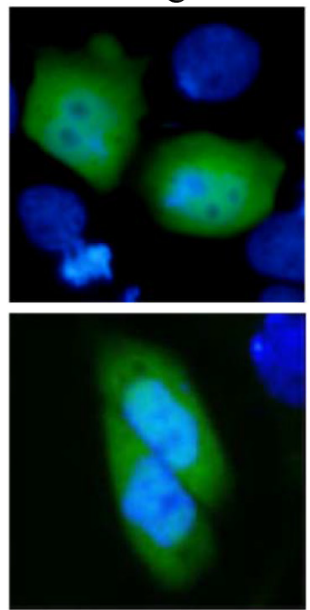

Figure 4: Verification the subcellular localization of some EBV representative proteins fused with Flag tag from each category (Tables 1 to 3) using IFA. The plasmids expressing Flag fused BFRF3 and BMRF1 from nuclear localization, BSLF1 and BGLF1 from cytoplasmic localization, BGLF2 and BSRF1 from pan-cellular localization were transfected into COS-7 cells, and cells were subjected to IFA $24 \mathrm{~h}$ after transfection using anti-Flag mAb and FITC-conjugated goat anti-mouse IgG. Pictures were obtained using a Zeiss Axiovert 200M microscope. The same magnification was used in all panels. Representative fluorescence images of the vast majority live cells expressing indicated fusion protein were shown. Cells were counterstained with Hoechst to visualize the nuclear DNA. All scale bars indicate $10 \mu \mathrm{m}$. 
Table 1: Nuclear localization summary of EBV-encoded proteins

\begin{tabular}{|c|c|c|c|c|}
\hline No. & Protein name(s) & Function/description \# & $\begin{array}{l}\text { COS-7 subcellular } \\
\text { localization }\end{array}$ & $\begin{array}{l}\text { Literature } \\
\text { localization and } \\
\text { references }\end{array}$ \\
\hline 1 & BORF1 ${ }^{\mathrm{c}}$ & $\begin{array}{l}\text { Assembly/maturation, minor capsid protein- } \\
\text { binding protein (mCP-BP), homology with } \\
\text { triplex protein HSV-1 VP19C, VZV ORF20, } \\
\text { MCMV M46 and KSHV ORF62 }\end{array}$ & Subnuclear & $\begin{array}{l}\text { Pan-nuclear }{ }^{a}[6] \\
\text { Speckles in the nucleus } \\
\qquad{ }^{b}[48]\end{array}$ \\
\hline 2 & $\begin{array}{l}\text { BSLF2/BMLF1 }{ }^{\mathrm{t}} \\
(\mathrm{EB} 2, \mathrm{Mta}, \mathrm{SM})\end{array}$ & $\begin{array}{l}\text { mRNA-export factor, mRNA splicing, } \\
\text { interaction with human Spen proteins, } \\
\text { homology with HSV-1 UL54 (ICP27), VZV } \\
\text { ORF4, MCMV M69 and KSHV ORF57 }\end{array}$ & $\begin{array}{l}\text { Subnuclear, nucleolus } \\
\text { like }\end{array}$ & N/A \\
\hline 3 & $\begin{array}{c}\text { EBNA3A }^{1} \\
(\mathrm{BLRF} 3 / \mathrm{BERF} 1)\end{array}$ & $\begin{array}{c}\text { Latency nuclear antigen } 3 \mathrm{~A} \text {, negative effect } \\
\text { on transactivator EBNA-2 and cell cycle, } \\
\text { essential for immortalization }\end{array}$ & $\begin{array}{l}\text { Pan-nuclear, without } \\
\text { nucleolus }\end{array}$ & Pan-nuclear ${ }^{a}[6,49]$ \\
\hline 4 & $\begin{array}{l}\text { BZLF1 }{ }^{\mathrm{t}} \\
(\text { Zta, Z, Zebra, } \\
\text { EB1) }\end{array}$ & $\begin{array}{l}\text { Trans-activator ZEBRA, origin binding } \\
\text { protein (EB1, Zta), bZip similar to CCAAT/ } \\
\text { enhancer binding protein, homology with } \\
\text { KSHV K08 }\end{array}$ & $\begin{array}{l}\text { Pan-nuclear, without } \\
\text { nucleolus }\end{array}$ & $\begin{array}{l}\text { Pan-nuclear }{ }^{a}[6] \\
\text { Nuclear }^{b}[50]\end{array}$ \\
\hline 5 & RPMS1 ${ }^{u}$ & Unknown function & $\begin{array}{l}\text { Subnuclear, nucleolus } \\
\text { like }\end{array}$ & Pan-nuclear ${ }^{a}[34,51]$ \\
\hline 6 & $\begin{array}{l}\text { BMLF1 }{ }^{\mathrm{t}} \\
(\mathrm{Mta})\end{array}$ & $\begin{array}{l}\text { Immediate-early transactivator, part of } \\
\text { BSLF2/BMLF1 protein }\end{array}$ & $\begin{array}{l}\text { Subnuclear, nucleolus } \\
\text { like }\end{array}$ & $\begin{array}{l}\text { Nuclear and speckles } \\
\text { in the nucleus }{ }^{a}[52 \text {, } \\
\text { 53] } \\
\text { Nuclear }{ }^{b}[50]\end{array}$ \\
\hline 7 & BXRF1 ${ }^{u}$ & $\begin{array}{c}\text { Nucleoprotein, homology with HSV-1 UL24, } \\
\text { VZV ORF35, MCMV M76 and KSHV } \\
\text { ORF20 }\end{array}$ & $\begin{array}{l}\text { Subnuclear, nucleolus } \\
\text { like }\end{array}$ & $\mathrm{N} / \mathrm{A}$ \\
\hline 8 & BALF2 ${ }^{\mathrm{r}}$ & $\begin{array}{l}\text { Major ssDNA binding protein, tegument } \\
\text { protein, part of replication fork / machinery, } \\
\text { homology with HSV-1 UL29, VZV ORF29, } \\
\text { MCMV M57 and KSHV ORF6 }\end{array}$ & $\begin{array}{l}\text { Pan-nuclear, without } \\
\text { nucleolus }\end{array}$ & Pan-nuclear ${ }^{a}[6]$ \\
\hline 9 & BMRF1 ${ }^{r}$ & $\begin{array}{c}\text { DNA polymerase processivity factor, } \\
\text { transcriptional transactivators, sliding clamp, } \\
\text { early antigen protein D (EA-D, polymerase } \\
\text { accessory protein), homology with HSV-1 } \\
\text { UL42, VZV ORF16, MCMV M44 and KSHV } \\
\text { ORF59 }\end{array}$ & Pan-nuclear & Pan-nuclear ${ }^{a}[6]$ \\
\hline 10 & BLLF2 ${ }^{\mathrm{T}}$ & Hypothetical protein, unknown function & $\begin{array}{l}\text { Subnuclear, nucleolus } \\
\text { like }\end{array}$ & Pan-nuclear ${ }^{a}[6]$ \\
\hline 11 & BFLF2 m & $\begin{array}{l}\text { Nuclear membrane phosphoprotein, part } \\
\text { of intracellular virions, egress protein, } \\
\text { herpesvirus UL31-like protein, complex with } \\
\text { BFRF1, homology with HSV-1 UL31, VZV } \\
\text { ORF27, MCMV M53 and KSHV ORF69 }\end{array}$ & Pan-Nuclear & Nuclear $^{a}[54]$ \\
\hline 12 & BdRF1 ${ }^{c}$ & $\begin{array}{c}\text { Capsid scaffolding protein, homology with } \\
\text { HSV-1 UL26.5, VZV ORF33.5, MCMV } \\
\text { M80.5 and KSHV ORF17.5 }\end{array}$ & $\begin{array}{l}\text { Pan-nuclear, without } \\
\text { nucleolus }\end{array}$ & $\mathrm{N} / \mathrm{A}$ \\
\hline
\end{tabular}

(Continued) 


\begin{tabular}{|c|c|c|c|c|}
\hline No. & Protein name(s) & Function/description \# & $\begin{array}{l}\text { COS-7 subcellular } \\
\text { localization }\end{array}$ & $\begin{array}{l}\text { Literature } \\
\text { localization and } \\
\text { references }\end{array}$ \\
\hline 13 & $\begin{array}{l}\text { EBNA1 }^{1} \\
\text { (BKRF1) }\end{array}$ & $\begin{array}{l}\text { Latency nuclear antigen 1, assures EBV } \\
\text { episome maintenance replication, Gly-rich } \\
\text { domain, essential for immortalization }\end{array}$ & Pan-nuclear & Nuclear ${ }^{a / b}[55]$ \\
\hline 14 & BLLF3 ${ }^{n}$ & $\begin{array}{c}\text { dUTP pyrophosphatase, dUTPase, homology } \\
\text { with HSV-1 UL50, VZV ORF8, MCMV M72 } \\
\text { and KSHV ORF54 }\end{array}$ & $\begin{array}{l}\text { Nuclear obviously }> \\
\text { Cytoplasmic, without } \\
\text { nucleolus }\end{array}$ & Pan-Nuclear ${ }^{\mathrm{a}}[6]$ \\
\hline 15 & BGLF5 $^{\mathrm{r}}$ & $\begin{array}{c}\text { Alkaline exonuclease, involved together with } \\
\text { BALF2 in DNA recombination, homology } \\
\text { with HSV-1 UL12, VZV ORF48, MCMV } \\
\text { M98 and KSHV ORF37 }\end{array}$ & $\begin{array}{l}\text { Nuclear obviously }> \\
\text { Cytoplasmic, without } \\
\text { nucleolus }\end{array}$ & $\begin{array}{c}\text { Nucleus and cytoplasm } \\
\text { a }[56] \\
\text { Nuclear }{ }^{\mathrm{a}}[57]\end{array}$ \\
\hline 16 & BRRF1 ${ }^{t}$ & $\begin{array}{l}\mathrm{Na} \text {, transcription factor, enhancement of the } \\
\text { induction of the lytic cycle, homology with } \\
\text { KSHV ORF49 }\end{array}$ & $\begin{array}{l}\text { Nuclear obviously }> \\
\text { Cytoplasmic, without } \\
\text { nucleolus }\end{array}$ & Nuclear $^{a}[58]$ \\
\hline 17 & BCRF2 u & Unknown function & $\begin{array}{l}\text { Nuclear obviously }> \\
\text { Cytoplasmic, without } \\
\text { nucleolus }\end{array}$ & N/A \\
\hline 18 & BDLF4 u & $\begin{array}{l}\text { Putative metal binding protein (gp115), } \\
\text { homology with MCMV M92 and KSHV } \\
\text { ORF31 }\end{array}$ & Nuclear $>$ Cytoplasmic & Pan-Cellular ${ }^{\mathrm{a}}[6]$ \\
\hline 19 & BARF0 ${ }^{u}$ & $\begin{array}{c}\text { Start at amino acid } 298 \text { of SWISS-PROT, } \\
\text { homology with rhesus LCV }\end{array}$ & $\begin{array}{l}\text { Nuclear obviously }> \\
\text { Cytoplasmic }\end{array}$ & Nuclear $^{\mathrm{a}}[59,60]$ \\
\hline 20 & BBLF1 ${ }^{\mathrm{T}}$ & $\begin{array}{l}\text { Myristoylated phosphoprotein in tegument } \\
\text { (MyrP), homology with HSV-1 UL11, VZV } \\
\text { ORF49, MCMV M99 and KSHV ORF38 }\end{array}$ & $\begin{array}{l}\text { Nuclear obviously }> \\
\text { Cytoplasmic, without } \\
\text { nucleolus }\end{array}$ & $\begin{array}{c}\text { Pan-Cellular or } \\
\text { Cytoplasmic }>\text { Nuclear } \\
\text { a }[6] \\
\text { trans-Golgi network } \\
(\mathrm{TGN})^{\mathrm{a} / \mathrm{b}}[20]\end{array}$ \\
\hline 21 & $\mathrm{BFRF}^{\mathrm{c}}$ & $\begin{array}{c}\text { Smallest capsid protein (sCP) on outer capsid } \\
\text { surface, homology with HSV-1 UL35 (VP26), } \\
\text { VZV ORF23, MCMV M48.2 and KSHV } \\
\text { ORF65 }\end{array}$ & $\begin{array}{c}\text { Nuclear obviously }> \\
\text { Cytoplasmic, without } \\
\text { nucleolus }\end{array}$ & $\begin{array}{l}\text { Pan-Nuclear a }[6] \\
\text { Nuclear }{ }^{\mathrm{b}}[61]\end{array}$ \\
\hline 22 & $\mathrm{BGLF}^{\mathrm{T}}$ & $\begin{array}{l}\text { gp118, not included in virions, homology with } \\
\text { HSV-1 UL14, VZV ORF46, MCMV M95 and } \\
\text { KSHV ORF34 }\end{array}$ & $\begin{array}{l}\text { Nuclear obviously }> \\
\text { Cytoplasmic }\end{array}$ & $\begin{array}{c}\text { Nuclear }>\text { Cytoplasmic } \\
{ }^{\mathrm{a}}[6]\end{array}$ \\
\hline 23 & BGLF4 ${ }^{n}$ & $\begin{array}{c}\text { Ser/Thr kinase, phosphorylation of nucleoside } \\
\text { analogues, homology with HSV-1 UL13, } \\
\text { VZV ORF47, MCMV M97 and KSHV } \\
\text { ORF36 }\end{array}$ & $\begin{array}{l}\text { Nuclear obviously }> \\
\text { Cytoplasmic }\end{array}$ & $\begin{array}{c}\text { Nuclear }{ }^{\mathrm{a}}[62] \\
\text { Nuclear }>\text { Cytoplasmic } \\
\text { a }[6] \\
\text { Nuclear, a small } \\
\text { portion is distributed } \\
\text { in the cytoplasm at } \\
\text { the late stage of virus } \\
\text { replication }{ }^{\mathrm{b}}[63]\end{array}$ \\
\hline 24 & $\mathrm{BKRF}^{\mathrm{T}}$ & $\begin{array}{l}\text { Tegument phosphoprotein, homology with } \\
\text { KSHV ORF45 }\end{array}$ & $\begin{array}{l}\text { Nuclear obviously }> \\
\text { Cytoplasmic some } \\
\text { with multiple small } \\
\text { foci in the nucleus }\end{array}$ & Pan-Nuclear ${ }^{\mathrm{a}}[6]$ \\
\hline
\end{tabular}

(Continued) 


\begin{tabular}{|c|c|c|c|c|}
\hline No. & Protein name(s) & Function/description \# & $\begin{array}{l}\text { COS-7 subcellular } \\
\text { localization }\end{array}$ & $\begin{array}{l}\text { Literature } \\
\text { localization and } \\
\text { references }\end{array}$ \\
\hline 25 & $\begin{array}{l}\text { BRLF1 }{ }^{\mathrm{t}} \\
(\mathrm{Rta}, \mathrm{R})\end{array}$ & $\begin{array}{c}\text { Transcriptional activator dimeric (TAF50), } \\
\text { homology with KSHV ORF50 }\end{array}$ & $\begin{array}{l}\text { Nuclear obviously } \\
\text { > Cytoplasmic, } \\
\text { Cytoplasmic }> \\
\text { Nuclear, Pan-cellular }\end{array}$ & $\begin{array}{l}\text { Pan-Nuclear, Pan- } \\
\text { Cytoplasmic, Pan- } \\
\text { Cellular }{ }^{\mathrm{a}}[6,64] \\
\text { Cytoplasmic and } \\
\text { nuclear }{ }^{\mathrm{b}}[50]\end{array}$ \\
\hline 26 & BLRF2 $^{\mathrm{T}}$ & $\begin{array}{l}\text { Tegument protein, homology with KSHV } \\
\text { ORF52 }\end{array}$ & $\begin{array}{c}\text { Nuclear }> \\
\text { Cytoplasmic, with } \\
\text { speckles }\end{array}$ & $\begin{array}{c}\text { Nuclear }>\text { Cytoplasmic } \\
\text { a }[6] \\
\text { Relocalized from } \\
\text { the nucleus to the } \\
\text { cytoplasm }{ }^{\text {b }}[19]\end{array}$ \\
\hline 27 & $\mathrm{BVRF} 2^{\mathrm{c}}$ & $\begin{array}{c}\text { Proteinase/scaffold protein, capsid } \\
\text { maturational protease, homology with HSV-1 } \\
\text { UL26, VZV ORF33, MCMV M80 and KSHV } \\
\text { ORF17 }\end{array}$ & $\begin{array}{l}\text { Nuclear slightly }> \\
\text { Cytoplasmic }\end{array}$ & Pan-Nuclear a ${ }^{[6]}$ \\
\hline 28 & BOLF1 $^{\mathrm{T}}$ & $\begin{array}{l}\text { Tegument large tegument protein-binding } \\
\text { protein (LTPBP) }\end{array}$ & $\begin{array}{c}\text { Nuclear obviously }> \\
\text { Cytoplasmic, without } \\
\text { nucleolus }\end{array}$ & N/A \\
\hline
\end{tabular}

a: transfection

b: infection

N/A: Not Detected

$\mathrm{r}$ : replication related protein

$\mathrm{n}$ : nucleotide metabolism related protein

$\mathrm{t}$ : transcription related protein

$\mathrm{p}$ : packaging related protein

1: latency related protein

m: membrane (or glycosylated) protein

c: capsid related protein

$\mathrm{T}$ : tegument protein

u: unkown function protein

\# Function/Description column compiled the following references: Tarbouriech et al. [5] and Salsman et al. [6].

minor discrepancies in localization were detected for 4 proteins (BLLF2, BKRF4, BLRF2 and BBRF1) diverse from previous studies, however, significant discrepancies in localization were observed for 5 proteins (BDLF4, BSRF1, BBLF1, BALF5 and BTRF1) distinct from previous results. Moreover, the subcellular localizations of some Flag-fused representative proteins from each category (BFRF3 and BMRF1 from nuclear localization, BSLF1 and BGLF1 from cytoplasmic localization, BGLF2 and BSRF1 from pan-cellular localization) were consistent with the subcellular localizations of those fused with EYFP tag (Figure 4), further making the results more convincing.

Some discrepancies could not be unexpected with localizations assessed in the course of viral infection since the presence of interplays between viral proteins can change the localization of the individual proteins. The localization discrepancies of specific proteins might also be associated with protein expression levels or the presence of a tag. Not surprised, this initial analysis 
Table 2: Cytoplasmic localization summary of EBV-encoded proteins

\begin{tabular}{|c|c|c|c|c|}
\hline No. & Protein name(s) & Function/description \# & $\begin{array}{l}\text { COS-7 subcellular } \\
\text { localization }\end{array}$ & $\begin{array}{l}\text { Literature localization } \\
\text { and references }\end{array}$ \\
\hline 1 & BILF2 m & $\begin{array}{l}\text { Potential membrane glycoprotein gp } 55 / 80 \text {, } \\
\text { Ig-like, gp } 78\end{array}$ & $\begin{array}{l}\text { Subcytoplasmic, in } \\
\text { intense perinuclear, } \\
\text { ER or Golgi like }\end{array}$ & N/A \\
\hline 2 & BLRF1 ${ }^{\mathrm{m}}$ & $\begin{array}{l}\text { Membrane glycoprotein gN, part of the gM- } \\
\text { gN complex, part of the envelope-tegument } \\
\text { interaction, homology with HSV-1 UL49A, } \\
\text { VZV ORF9a, HHV5 UL73, MCMV M73 and } \\
\text { KSHV ORF53 }\end{array}$ & $\begin{array}{l}\text { Subcytoplasmic, ER } \\
\text { like }\end{array}$ & $\begin{array}{l}\text { Subcytoplasmic, ER- } \\
\quad \text { like }^{a}[6]\end{array}$ \\
\hline 3 & BXLF2 ${ }^{m}$ & $\begin{array}{c}\text { Glycoprotein H, gp85, part of gHgLgp42, } \\
\text { homology with HSV-1 UL22, VZV ORF37, } \\
\text { MCMV M75 and KSHV ORF22 }\end{array}$ & Pan-Cytoplasmic & $\begin{array}{l}\text { Cytoplasm and nuclear } \\
\operatorname{rim}^{a}[65]\end{array}$ \\
\hline 4 & BLLF1 ${ }^{\mathrm{m}}$ & $\begin{array}{c}\text { Envelope glycoprotein gp340/gp220, gp350, } \\
\text { initial cell binding through complement } \\
\text { receptor } 2(\mathrm{CR} 2, \mathrm{CD} 21)\end{array}$ & $\begin{array}{l}\text { Subcytoplasmic, } \\
\text { perinuclear } \\
\text { concentration, ER or } \\
\text { Golgi like, }\end{array}$ & $\begin{array}{l}\text { Golgi and plasma } \\
\text { membrane }^{b}[20,66]\end{array}$ \\
\hline 5 & BKRF2 ${ }^{m}$ & $\begin{array}{c}\text { Glycoprotein L, gp25, in gL-gH complex } \\
\text { involved in viral fusion together with gB, } \\
\text { homology with HSV-1 UL1, VZV ORF60, } \\
\text { MCMV M115 and KSHV ORF47 }\end{array}$ & $\begin{array}{l}\text { Subcytoplasmic, in } \\
\text { intense perinuclear }\end{array}$ & N/A \\
\hline 6 & BFLF1 ${ }^{p}$ & $\begin{array}{c}\text { Major envelope protein, plays role in DNA } \\
\text { packaging, cytosolic zinc-binding protein, } \\
\text { cysteine rich, homology with HSV-1 UL32, } \\
\text { VZV ORF26, MCMV M52 and KSHV } \\
\text { ORF68 }\end{array}$ & Pan-Cytoplasmic & N/A \\
\hline 7 & BBLF $2 / 3^{r}$ & $\begin{array}{c}\text { Primase-associated factor, spliced, full } \\
\text { sequence not in DB, part of helicase-primase } \\
\text { complex }\end{array}$ & Pan-Cytoplasmic & $\begin{array}{c}\text { Pan-Cellular, } \\
\text { Cytoplasmic }>\text { Nuclear } \\
{ }^{a}[6] \\
\text { Cytoplasmic } \\
\text { localization or mixed } \\
\text { cytoplasmic plus } \\
\text { nuclear localization }{ }^{a} \\
{[67]}\end{array}$ \\
\hline 8 & $\begin{array}{l}\text { BNLF1 } 1 \\
(\mathrm{LMP} 1)\end{array}$ & $\begin{array}{l}\text { Latent membrane protein, interferes with } \\
\text { signalling, TRAF-binding through CTAR1 } \\
\text { and 2, essential for immortalization }\end{array}$ & $\begin{array}{l}\text { Subcytoplasmic, with } \\
\text { speckle structures }\end{array}$ & $\begin{array}{l}\text { Cytosolic, cytoskeletal, } \\
\text { lipid raft and internal } \\
\text { perinuclear membranes } \\
\qquad a[68]\end{array}$ \\
\hline 9 & $\mathrm{LMP} \mathrm{A}^{1}$ & $\begin{array}{l}\text { Latent membrane protein, interference with } \\
\text { protein kinase signalling, gene terminal } \\
\text { protein, essential for immortalization, } \\
\text { homology with KSHV K15 }\end{array}$ & $\begin{array}{l}\text { Subcytoplasmic, } \\
\text { perinuclear speckle } \\
\text { concentration }\end{array}$ & $\begin{array}{l}\text { Perinuclear regions, } \\
\text { plasma membrane }^{a} \\
\text { [69] }\end{array}$ \\
\hline 10 & LMP2B $^{1}$ & $\begin{array}{l}\text { Latent membrane protein, negative regulator } \\
\text { of LMP- } 2 \mathrm{~A}\end{array}$ & $\begin{array}{l}\text { Subcytoplasmic, } \\
\text { nuclear membrane, } \\
\text { like trans-Golgi } \\
\text { network }\end{array}$ & $\begin{array}{l}\text { Perinuclear regions and } \\
\text { trans-Golgi network }{ }^{a} \\
{[69,70]}\end{array}$ \\
\hline
\end{tabular}

(Continued) 


\begin{tabular}{|c|c|c|c|c|}
\hline No. & Protein name(s) & Function/description \# & $\begin{array}{l}\text { COS-7 subcellular } \\
\text { localization }\end{array}$ & $\begin{array}{c}\text { Literature localization } \\
\text { and references }\end{array}$ \\
\hline 11 & BCRF1 ${ }^{\mathrm{t}}(\mathrm{vIL}-10)$ & $\begin{array}{l}\text { Viral interleukin-10 homologue precursor, } \\
\text { vIL-10, homology with MCMV M87 and } \\
\text { KSHV ORF24 }\end{array}$ & Pan-Cytoplasmic & Subcytoplasmic $^{a}[6]$ \\
\hline 12 & BRRF2 ${ }^{\mathrm{T}}$ & $\begin{array}{l}\text { Unknown function, homology with KSHV } \\
\text { ORF48 }\end{array}$ & Pan-Cytoplasmic & Subcytoplasmic $^{a}[6]$ \\
\hline 13 & BSLF1 ${ }^{n}$ & $\begin{array}{c}\text { Primase, DNA helicase-primase component, } \\
\text { homology with HSV-1 UL52, VZV ORF6, } \\
\text { MCMV M70 and KSHV ORF56 }\end{array}$ & Pan-Cytoplasmic & Pan-cytoplasmic ${ }^{a}[6]$ \\
\hline 14 & BFRF2 u & $\begin{array}{l}\text { Possible capsid protein, not included in } \\
\text { virions, unknown function, homology with } \\
\text { MCMV M49 and KSHV ORF66 }\end{array}$ & Pan-Cytoplasmic & Pan-cytoplasmic ${ }^{a}[6]$ \\
\hline 15 & BBRF1 ${ }^{c}$ & $\begin{array}{c}\text { Minor capsid protein portal protein UL6 } \\
\text { homologue, homology with HSV-1 UL6, } \\
\text { VZV ORF54, MCMV M104 and KSHV } \\
\text { ORF43 }\end{array}$ & $\begin{array}{l}\text { Subcytoplasmic, } \\
\text { with speckles in the } \\
\text { cytoplasmic }\end{array}$ & Pan-cytoplasmic ${ }^{a}[6]$ \\
\hline 16 & BMRF2 m & $\begin{array}{l}\text { Receptor for cellular integrins, needed for } \\
\text { infection of epithelial cells, } 10 \text { TM helices, } \\
\text { RGD motif, membrane accociated protein, } \\
\text { homology with KSHV ORF58 }\end{array}$ & $\begin{array}{c}\text { Subcytoplasmic, } \\
\text { cytoplasmic obviously } \\
\text { > Nuclear, perinuclear } \\
\text { concentration, ER or } \\
\text { Golgi like }\end{array}$ & $\begin{array}{c}\text { Cytoplasm and } \\
\text { membrane }{ }^{\mathrm{a} / \mathrm{b}}[71] \\
\text { ER and Golgi }{ }^{\mathrm{a}}[72]\end{array}$ \\
\hline 17 & BALF1 ${ }^{t}$ & $\begin{array}{l}\text { Bcl-2 homologue, negative regulator of anti- } \\
\text { apoptosis protein BHRF1 }\end{array}$ & Pan-Cytoplasmic & $\begin{array}{l}\text { Cytoplasmic }>\text { Nuclear } \\
\qquad{ }^{\text {a }}[6] \\
\text { Cytoplasmic }^{\text {a }}[73]\end{array}$ \\
\hline 18 & ECRF4 u & Unkown function & $\begin{array}{l}\text { Cytoplasmic obviously } \\
\quad>\text { Nuclear }\end{array}$ & $\mathrm{N} / \mathrm{A}$ \\
\hline 19 & BALF4 ${ }^{\mathrm{m}}$ & $\begin{array}{c}\text { Glycoprotein B, glycoprotein 110, fusion and } \\
\text { co-receptor binding, homology with HSV-1 } \\
\text { UL27 (gB), VZV ORF31, MCMV M55 and } \\
\text { KSHV ORF8 }\end{array}$ & $\begin{array}{c}\text { Cytoplasmic obviously } \\
>\text { Nuclear, intense } \\
\text { in perinuclear } \\
\text { cytoplasmic with some } \\
\text { patches, ER or Golgi } \\
\text { like }\end{array}$ & $\begin{array}{c}\text { Cytoplasmic, } \\
\text { perinuclear and nuclear } \\
\text { membranes }{ }^{a}[74] \\
\text { Cytoplasmic, nuclear } \\
\text { membranes, ER and } \\
\text { the inner/outer nuclear } \\
\text { membranes, plasma } \\
\text { membrane and cell } \\
\text { surface }^{\mathrm{b}}[66,75]\end{array}$ \\
\hline 20 & BILF1 m & $\begin{array}{c}\text { G-protein coupled receptor (G-PCR), includes } \\
7 \text { transmembrane helices, } 6 \text { glycosylation } \\
\text { sites, } 2 \text { disulfide bridges gP64 }\end{array}$ & $\begin{array}{l}\text { Pan-Cytoplasmic, } \\
\text { plasma membrane like }\end{array}$ & $\begin{array}{l}\text { Plasma membrane }{ }^{\mathrm{a}} \\
\qquad[76,77] \\
\text { Cytoplasmic membrane } \\
\text { b }[78]\end{array}$ \\
\hline 21 & BARF1 ${ }^{t}$ & $\begin{array}{l}\text { CD80 homologue (p33), oncogene, soluble } \\
\text { glycoprotein, includes } 2 \text { Ig domains, binds } \\
\text { CSF-1, homology with HSV-1 UL40, VZV } \\
\text { ORF18 and KSHV ORF60 }\end{array}$ & $\begin{array}{l}\text { Cytoplasmic obviously } \\
\quad>\text { Nuclear }\end{array}$ & 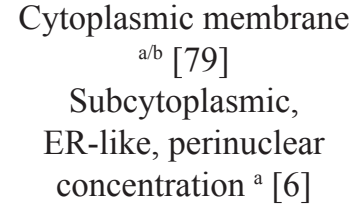 \\
\hline 22 & BVLF1 u & Unknown function & $\begin{array}{l}\text { Cytoplasmic obviously } \\
\quad>\text { Nuclear }\end{array}$ & N/A \\
\hline 23 & LF1 u & $\begin{array}{l}\text { Contains a dUTPase like domain, } \gamma \text {-herpes } \\
\text { ORF10 family }\end{array}$ & $\begin{array}{l}\text { Cytoplasmic obviously } \\
\quad>\text { Nuclear }\end{array}$ & $\mathrm{N} / \mathrm{A}$ \\
\hline
\end{tabular}

(Continued) 


\begin{tabular}{|c|c|c|c|c|}
\hline No. & Protein name(s) & Function/description \# & $\begin{array}{l}\text { COS-7 subcellular } \\
\text { localization }\end{array}$ & $\begin{array}{c}\text { Literature localization } \\
\text { and references }\end{array}$ \\
\hline 24 & $\mathrm{BNLF} 2 \mathrm{a}^{\mathrm{u}}$ & Potential membrane protein & $\begin{array}{l}\text { Cytoplasmic obviously } \\
>\text { Nuclear, ER or } \\
\text { Golgi like }\end{array}$ & $\begin{array}{l}\text { Pan-Cytoplasmic a }[6] \\
\text { ER }^{\text {a }}[80]\end{array}$ \\
\hline 25 & $\mathrm{BGLF}^{\mathrm{T}}$ & $\begin{array}{c}\text { Potential tegument protein (gp115), homology } \\
\text { with HSV-1 UL17, VZV ORF43, MCMV } \\
\text { M93 and KSHV ORF32 }\end{array}$ & Pan-Cytoplasmic & Pan-Cytoplasmic a $[6]$ \\
\hline 26 & BORF2 ${ }^{n}$ & $\begin{array}{c}\text { Ribonucleotide-reductase, large subunit, } 140 \\
\text { kDa, homology with HSV-1 UL39, VZV } \\
\text { ORF19, MCMV M45 and KSHV ORF61 }\end{array}$ & $\begin{array}{l}\text { Cytoplasmic obviously } \\
>\text { Nuclear, with } \\
\text { punctates in the } \\
\text { cytoplasmic }\end{array}$ & $\begin{array}{l}\text { Subcytoplasmic, } \\
\text { punctate cytoplasmic } \\
\text { crystal-like structures } \\
\qquad \text { a }[6]\end{array}$ \\
\hline 27 & BXLF1 ${ }^{n}$ & $\begin{array}{l}\text { Thymidine kinase, homology with HSV-1 } \\
\text { UL23, VZV ORF36 and KSHV ORF21 }\end{array}$ & $\begin{array}{l}\text { Subcytoplasmic, } \\
\text { irregularly shaped } \\
\text { cytoplasmic structures }\end{array}$ & $\begin{array}{c}\text { Subcytoplasmic, } \\
\text { irregularly shaped } \\
\text { cytoplasmic structures } \\
\text { a }[6]\end{array}$ \\
\hline 28 & BBLF4 ${ }^{r}$ & $\begin{array}{c}\text { Helicase, part of helicase-primase complex, } \\
\text { homology with HSV-1 UL5, VZV ORF55, } \\
\text { MCMV M105 and KSHV ORF44 }\end{array}$ & $\begin{array}{l}\text { Cytoplasmic obviously } \\
\quad>\text { Nuclear }\end{array}$ & $\begin{array}{c}\text { Cytoplasmic }>\text { Nuclear } \\
\text { a }[81]\end{array}$ \\
\hline 29 & BALF5 $^{r}$ & $\begin{array}{c}\text { DNA polymerase, homology with HSV-1 } \\
\text { UL30, VZV ORF28, MCMV M54 and KSHV } \\
\text { ORF9 }\end{array}$ & Pan-Cytoplasmic & Nuclear $^{b}[21]$ \\
\hline 30 & BTRF1 ${ }^{\mathrm{c}}$ & $\begin{array}{l}\text { Hypothetical protein, involved in capsid } \\
\text { maturation, capsid-associated, homology with } \\
\text { HSV-1 UL21, VZV ORF38, MCMV M88 and } \\
\text { KSHV ORF23 }\end{array}$ & Pan-Cytoplasmic & $\begin{array}{c}\text { Nuclear }>\text { Cytoplasmic } \\
{ }^{\mathrm{a}}[6]\end{array}$ \\
\hline 31 & $\mathrm{LF} 2 \mathrm{u}$ & $\begin{array}{l}\text { Contains a dUTPase like domain, } \gamma \text {-herpes } \\
\text { ORF11 family }\end{array}$ & $\begin{array}{l}\text { Cytoplasmic, } \\
\text { cytoskeletal like }\end{array}$ & $\begin{array}{c}\text { Cytoplasmic, } \\
\text { cytoskeletal }^{a}[82]\end{array}$ \\
\hline 32 & BDLF2 $^{\mathrm{T}}$ & $\begin{array}{l}\text { Potential type II glycosylated envelope } \\
\text { protein, homology with KSHV ORF } 27\end{array}$ & $\begin{array}{l}\text { Subcytoplasmic, } \\
\text { with perinuclear } \\
\text { concentration }\end{array}$ & $\begin{array}{l}\text { Subcytoplasmic, ER- } \\
\text { like }^{a}[6,72]\end{array}$ \\
\hline
\end{tabular}

a: transfection

b: infection

N/A: Not Detected

r: replication related protein

$\mathrm{n}$ : nucleotide metabolism related protein

$\mathrm{t}$ : transcription related protein

p: packaging related protein

1: latency related protein

$\mathrm{m}$ : membrane (or glycosylated) protein

c: capsid related protein

$\mathrm{T}$ : tegument protein

$\mathrm{u}$ : unkown function protein

\# Function/Description column compiled the following references: Tarbouriech et al. [5] and Salsman et al. [6]. 
Table 3: Pan-cellular localization summary of EBV-encoded proteins

\begin{tabular}{|c|c|c|c|c|}
\hline No. & Protein name(s) & Function/description ${ }^{\#}$ & $\begin{array}{l}\text { COS-7 subcellular } \\
\text { localization }\end{array}$ & $\begin{array}{l}\text { Literature } \\
\text { localization and } \\
\text { references }\end{array}$ \\
\hline 1 & BDLF1 ${ }^{c}$ & $\begin{array}{c}\text { Minor capsid protein, homology with HSV-1 } \\
\text { UL18 (VP23), VZV ORF41, MCMV M85 } \\
\text { and KSHV ORF26 }\end{array}$ & $\begin{array}{l}\text { Pan-Cellular, without } \\
\text { nucleolus }\end{array}$ & Pan-Cellular ${ }^{a}[6,48]$ \\
\hline 2 & BBRF3 ${ }^{m}$ & $\begin{array}{l}\text { Integral membrane protein glycoprotein } \\
\text { M, part of gN-gM complex involved in } \\
\text { envelope-tegument interaction, homology } \\
\text { with HSV-1 UL10, VZV ORF50, MCMV } \\
\text { M100 and KSHV ORF39 }\end{array}$ & Pan-Cellular & N/A \\
\hline 3 & BDLF3 ${ }^{\mathrm{m}}$ & $\begin{array}{c}\text { Membrane glycoprotein (gp150), gp117, } \\
\text { homology with KSHV ORF28 }\end{array}$ & $\begin{array}{l}\text { Pan-cellular, with } \\
\text { punctate perinuclear } \\
\text { and cytoplasmic }\end{array}$ & $\begin{array}{l}\text { Subcytoplasmic, } \\
\text { punctate perinuclear } \\
\text { concentration }^{a}[6] \\
\text { Cytoplasmic }^{b}[83]\end{array}$ \\
\hline 4 & BZLF2 ${ }^{m}$ & $\begin{array}{l}\text { gp42, MHC class II binding protein, part of } \\
\text { gHgLgp42 complex }\end{array}$ & Plasma membrane & N/A \\
\hline 5 & BGRF1/BDRF1 ${ }^{p}$ & $\begin{array}{l}\text { DNA-packaging protein, terminase small } \\
\text { subunit, homology with HSV-1 UL15, VZV } \\
\text { ORF42, MCMV M89 and KSHV ORF29a }\end{array}$ & Pan-Cellular & $\mathrm{N} / \mathrm{A}$ \\
\hline 6 & BWRF1 ${ }^{1}$ & $\begin{array}{l}\text { EBNA-Lp (EBNA-5) nuclear } \\
\text { phosphoprotein, highly spliced, } 12 \\
\text { exons, proline-rich, enhances EBNA-2 } \\
\text { transactivation }\end{array}$ & $\begin{array}{l}\text { Pan-Cellular, with } \\
\text { speckles in cytoplasm } \\
\text { and perinuclear }\end{array}$ & N/A \\
\hline 7 & $\mathrm{BaRF} 1^{\mathrm{n}}$ & $\begin{array}{c}\text { Ribonucleotide reductase, small } 38 \mathrm{kDa} \\
\text { subunit, homology with HSV-1 UL40, VZV } \\
\text { ORF18 and KSHV ORF60 }\end{array}$ & Pan-Cellular & Pan-Cellular ${ }^{a}[6]$ \\
\hline 8 & BKRF3 ${ }^{n}$ & $\begin{array}{c}\text { Uracil DNA glycosylase, homology with } \\
\text { HSV-1 UL2, VZV ORF59, MCMV M114 } \\
\text { and KSHV ORF46 }\end{array}$ & Pan-Cellular & $\begin{array}{l}\text { Pan-Cellular }{ }^{a}[6,84] \\
\text { Translocated from the } \\
\text { cytoplasm into the } \\
\text { nucleus }{ }^{b}[21]\end{array}$ \\
\hline 9 & BFRF4 ${ }^{p}$ & $\begin{array}{c}\text { DNA-cleavage and packaging protein, part } \\
\text { of the DNA packaging machinery (BFRF0.5, } \\
\text { HS4BAM), homology with HSV-1 UL33, } \\
\text { VZV ORF25, MCMV M51 and KSHV } \\
\text { ORF67.5 }\end{array}$ & Pan-Cellular & N/A \\
\hline 10 & BHRF1 ${ }^{t}$ & $\begin{array}{c}\text { Early antigen protein } \mathrm{R}(\mathrm{EA}-\mathrm{R}) \text {, nuclear } \\
\text { antigen, anti-apoptotic factor Bcl-2 } \\
\text { homologue }\end{array}$ & $\begin{array}{l}\text { Pan-Cellular, with } \\
\text { speckles in cytoplasm } \\
\text { and perinuclear, } \\
\text { mitochondria like }\end{array}$ & $\begin{array}{l}\text { Mitochondria, ER and } \\
\text { nuclear membranes }{ }^{a} \\
\text { [85] } \\
\text { Mitochondria }^{b}[86]\end{array}$ \\
\hline 11 & LF3 u & Unknown function & Pan-Cellular & $\mathrm{N} / \mathrm{A}$ \\
\hline 12 & BSLF2 ${ }^{u}$ & $\begin{array}{c}\text { N-terminal fragment ( } 5^{\prime} \text { exon) of SM/EB2 } \\
\text { protein and part of BSLF2/BMLF1 protein, } \\
\text { homology with HSV-1 UL54, VZV ORF4, } \\
\text { MCMV M69 and KSHV ORF57 }\end{array}$ & $\begin{array}{l}\text { Pan-Cellular, without } \\
\text { nucleolus }\end{array}$ & Pan-Cellular $^{a}[6,48]$ \\
\hline
\end{tabular}

(Continued) 


\begin{tabular}{|c|c|c|c|c|}
\hline No. & Protein name(s) & Function/description \# & $\begin{array}{l}\text { COS-7 subcellular } \\
\text { localization }\end{array}$ & $\begin{array}{l}\text { Literature } \\
\text { localization and } \\
\text { references }\end{array}$ \\
\hline 13 & BGLF3.5 u & $\begin{array}{l}\text { Unknown function, homology with MCMV } \\
\text { M96 and KSHV ORF35 }\end{array}$ & $\begin{array}{l}\text { Pan-Cellular, without } \\
\text { nucleolus }\end{array}$ & $\mathrm{N} / \mathrm{A}$ \\
\hline 14 & BFRF1A $^{u}$ & Unknown function & $\begin{array}{l}\text { Pan-Cellular, without } \\
\text { nucleolus }\end{array}$ & $\mathrm{N} / \mathrm{A}$ \\
\hline 15 & BNLF2b ${ }^{u}$ & Potential gp141 & $\begin{array}{l}\text { Pan-Cellular, cell } \\
\text { membrane }\end{array}$ & $\mathrm{N} / \mathrm{A}$ \\
\hline 16 & $\begin{array}{l}\text { BcRF1 u } \\
\text { (UL87) }\end{array}$ & $\begin{array}{c}\text { Unknown function, herpesvirus UL87 } \\
\text { family, homology with MCMV M87 and } \\
\text { KSHV ORF24 }\end{array}$ & $\begin{array}{l}\text { Pan-cellular, with } \\
\text { speckle cytoplasmic } \\
\text { structures }\end{array}$ & Subcytoplasmic $^{a}[6]$ \\
\hline 17 & BBRF2 ${ }^{\mathrm{T}}$ & $\begin{array}{l}\text { Unknown function, homology with HSV- } \\
1 \text { UL7, VZV ORF53, MCMV M103 and } \\
\text { KSHV ORF42 }\end{array}$ & Pan-Cellular & Pan-Cellular ${ }^{a}[6]$ \\
\hline 18 & BFRF1 ${ }^{\mathrm{m}}$ & $\begin{array}{l}\text { Nuclear membrane protein p38, } \\
\text { transmembrane with large cytoplasm } \\
\text { domain, complex with BFLF2, homology } \\
\text { with HSV-1 UL34, VZV ORF24, MCMV } \\
\text { M50 and KSHV ORF67 }\end{array}$ & $\begin{array}{l}\text { Subcytoplasmic } \\
\text { and perinuclear } \\
\text { region, with speckle } \\
\text { cytoplasmic structures }\end{array}$ & $\begin{array}{c}\text { Pan-Cytoplasmic and } \\
\text { perinuclear region }^{a} \\
{[6,87]} \\
\text { Nuclear envelope }^{b} \\
{[88]}\end{array}$ \\
\hline 19 & BGLF2 ${ }^{\mathrm{T}}$ & $\begin{array}{l}\text { MyrPBP, homology with HSV-1 UL16, } \\
\text { VZV ORF44, MCMV M94 and KSHV } \\
\text { ORF33 }\end{array}$ & $\begin{array}{l}\text { Pan-Cellular, without } \\
\text { nucleolus }\end{array}$ & $\begin{array}{l}\text { Pan-Cellular }{ }^{a}[6] \\
\text { Nuclei with granular } \\
\qquad b[89]\end{array}$ \\
\hline 20 & BSRF1 ${ }^{\mathrm{T}}$ & $\begin{array}{c}\text { Palmitoylated tegument protein (PalmP), } \\
\text { homology with HSV-1 UL51, VZV ORF7, } \\
\text { MCMV M71 and KSHV ORF55 }\end{array}$ & Pan-Cellular & $\begin{array}{l}\text { Subcytoplasmic, } \\
\text { perinuclear } \\
\text { concentration }^{a}[6]\end{array}$ \\
\hline 21 & BVRF1 ${ }^{\mathrm{T}}$ & $\begin{array}{l}\text { Capsid associated protein, portal plug (EC- } \\
\text { RF2), seals DNA inside capsid, homology } \\
\text { with HSV-1 UL25, VZV ORF34, MCMV } \\
\text { M77 and KSHV ORF19 }\end{array}$ & Pan-Cellular & $\begin{array}{c}\text { Pan-Cellular, } \\
\text { Cytoplasmic }>\text { Nuclear } \\
\qquad a[6]\end{array}$ \\
\hline
\end{tabular}

a: transfection

b: infection

N/A: Not Detected

r: replication related protein

$\mathrm{n}$ : nucleotide metabolism related protein

$\mathrm{t}$ : transcription related protein

p: packaging related protein

1: latency related protein

$\mathrm{m}$ : membrane (or glycosylated) protein

c: capsid related protein

$\mathrm{T}$ : tegument protein

$\mathrm{u}$ : unkown function protein

\# Function/Description column compiled the following references: Tarbouriech et al. [5] and Salsman et al. [6]. 
demonstrated that such high through-put localization screening will not precisely clarify the localization of every viral protein in the context of infection, but it did present that such an approach is suitable for analyzing the localization of the vast majority of viral proteins even during viral infection.

\section{DISCUSSION}

Herpesviruses are large DNA viruses that encode a variety of proteins for complicated interactions with host. For the sake of taking an investigation on the possible roles of the many uncharacterized EBV-encoded proteins, the genomic expression libraries of EBV were constructed and screened to explore the complete intracellular localization map of almost all EBV proteins in mammalian cells. However, when we were cloning EBV genes, the subcellular localizations of 61 from 81 proteins have been probed by others to our knowledge (Tables 1 to 3 ), and with only slight differences, our results were good correlated with previously reported protein localizations, while new localization data was yielded for approximately 20 previously unlocalized proteins.

Almost one-third of EBV-encoded proteins localized principally in the nucleus (28 proteins) (Figure 1 and Table 1). Furthermore, 32 proteins primarily showed cytoplasmic or subcytoplasmic localization (Figure 2 and Table 2), and others localized throughout both compartments (often at unequal levels, 21 proteins) (Figure 3 and Table 3 ). It is of interest that $34.57 \%$ of the EBV-encoded proteins were detected in the nucleus, whereas only $12 \%$ of randomly selected cellular proteins showed nuclear localization [17]. A recent genome-wide subcellular localization study reported that human herpesvirus 8 (HHV-8, gammaherpesvirus) was found to have $51 \%$ cytoplasmic and $22 \%$ nuclear proteins (with $27 \%$ in both compartments) [18], indicates that EBV has a higher proportion of nuclear proteins than HHV-8. Nuclear predominance of EBVencoded proteins is in good consonance with the viral life cycle, which is preferentially associated with the nucleus.

In the present study, some of the results from transfection may be different from infection, because of the interactions of viral proteins during infection (data as shown in Tables 1 to 3 ). While these transfection results might not uncover the accurate subcellular localization of every viral proteins during infection, the subcellular localization map of individually expressed EBV-encoded proteins could offer helpful data to further examine the mechanism by which individual EBV-encoded protein effects on EBV pathogenesis.

Minor discrepancies were observed for only 4 proteins (BLLF2, BKRF4, BLRF2 and BBRF1) in this study [6, 19]. Specifically, BLLF2 and BKRF4 were detected exclusively in the nucleus by other investigators, whereas in our study BLLF2 showed subnuclear localization (nucleolus like), and BKRF4 showed obviously nuclear localization with multiple small foci. The minor capsid protein BBRF1 showed subcytoplasmic (with speckles in the cytoplasmic), which is different from the pan-cytoplasmic localization in previous reports. BLRF2 showed the fluorescence of nucleus is more than cytoplasm (with speckles), but this contrary to previous study in plasmid transfection, which may relocalized from the nucleus to the cytoplasm relied on the interaction with other viral proteins in the course of viral infection.

Significant differences were also observed for 5 proteins (BDLF4, BSRF1, BBLF1, BALF5 and BTRF1). In our study, BDLF4 showed the fluorescence in nucleus is more than cytoplasm, which is different from the pan-cellular localization reported by others [6]. The myristoylated phosphoprotein BBLF1 was found obviously nuclear localization without nucleolus that different with pan-cellular or cytoplasmic localization in previous study, which may depend on its myristoylation modification [6, 20]. BSRF1 showed pan-cellular localization, whereas it gave a subcytoplasmic or perinuclear concentration localization in a previous report [6], which may be explained by subtle difference in employ of a different cell lines. The DNA polymerase BALF5 localized exclusively in the cytoplasm, which is different from the predominantly nuclear localization during EBV infection [21]. It's reported that the nuclear transport of HHV-8 DNA polymerase holoenzyme is dependent on the nuclear localization signal (NLS) present on the processivity factor PF-8, since the catalytic subunit pol-8 lacks a functional NLS, and hence the two subunits are targeted into the nucleus as a complex [22]. Therefore we speculated that the transport of BALF5 from cytoplasm to nucleus requires the expression of additional viral factors, which could help BALF5 target into the nucleus for executing its function in viral DNA synthesis. In addition, BTRF1 was also detected only in the cytoplasm, which is demonstrated to be a nuclear-targeted protein (nuclear > cytoplasmic) previously.

Latency is a regulatory status, which may mainly rely on nuclear proteins to manipulate host cell and viral transcription. Compared with the intracellular localization map of HHV-8 [18], which found that all latencyassociated proteins showed a nuclear staining pattern, we detected only two latent related proteins EBNA3A (BLRF3/BERF1) and EBNA1 (BKRF1) localized in the nucleus, whereas the nuclear phosphoprotein BWRF1, latent membrane protein BNLF1 (LMP1), LMP2A and LMP2B showed pan-cellular (with speckles in cytoplasm and perinuclear), subcytoplasmic (with speckle cytoplasmic structures), perinuclear speckle concentration and nuclear membrane (like trans-Golgi network) localization, respectively. This disparity may be due to the different viral life cycle between EBV and HHV-8.

The assembly compartment for viral proteins in the host cell is probably relevant to its subcellular localization. EBV contains 13 membrane related 
protein, and 7 glycoproteins (BLLF1/gp350, BXLF2/ $\mathrm{gH}, \mathrm{BALF} 4 \mathrm{gB}, \mathrm{BBRF} / \mathrm{gM}, \mathrm{BLRF} 1 / \mathrm{gN}, \mathrm{BDLF} 3 / \mathrm{gp} 150$ and $\mathrm{BKRF} 2 / \mathrm{gL}$ ) are incorporated into its envelope [5, $8]$, which play crucial roles during virus infection. Besides, BILF2/gp55/80, a predicted membrane protein, also perhaps targets to the envelope. In this study, most of these proteins exhibited pan-cytoplasmic, subcytoplasmic, membraneous or pan-cellular localization, without nuclear or subnuclear localization (Figures 2 and 3, Tables 2 and 3). This is high concordance with the compartment where the envelope assembling occurs. Other 4 membrane proteins (BZLF2/ gp42, BILF1/G-PCR, BMRF2 and BFRF1) also showed plasma membrane, pan-cytoplasmic or subcytoplasmic and perinuclear localization (with speckle cytoplasmic structures), but only BFLF2 localized absolutely to the nucleus, which is in accordance with the subcellular localization of its homologue HSV-1 UL31.

In addition, it has been established that EBV virion has 6 proteins in its capsid (BDLF1, BORF1, BBRF1, BVRF2, BdRF1 and BFRF3) [5, 8], and BTRF1 is also predicted to be a potential protein that implicated in capsid maturation. In this work, BVRF2 and BFRF3 displayed enriched localization in the nucleus, and BORF1 (subnuclear) and BdRF1 showed complete localization in the nucleus, where the capsid assembling takes place. However, BDLF1, BBRF1 and BTRF1 demonstrated pan-cellular, pan-cytoplasmic or subcytoplasmic localization.

It's reported the replication of EBV involved in 6 proteins (BGLF5, BBLF2/3, BBLF4, BALF5, BALF2 and BMRF1) $[5,8]$. Interestingly, BGLF5, BBLF4, BALF2 and BMRF1 showed slightly or obviously nuclear localization in our job, this is correlates with the fact that EBV DNA replication occurs in the nucleus. However, BBLF2/3 and BALF5 appeared pan-cytoplasmic localization, which may be transported into the nucleus for viral DNA replication under the interaction with other viral proteins during infection [21]. The viral nucleotide metabolism is also important for virus replication, which implicated in 7 proteins (BaRF1, BKRF3, BLLF3, BGLF4, BSLF1, BXLF1 and BORF2) [5, 8]. Here, BaRF1, BKRF3, BLLF3 and BGLF4 showed apparently nuclear localization or pan-cellular localization, whereas BSLF1, BXLF1 and BORF2 showed pan-cytoplasmic or subcytoplasmic localization.

After herpesviral DNA replication, the RNA transcription is taken place later in the nucleus, and the transcription of EBV is associated with 9 proteins (BHRF1, BALF1, BARF1, BCRF1, BRRF1, BSLF2/ BMLF1, BZLF1, BRLF1 and BMLF1) [5, 8]. It is of interest that BHRF1, BARF1, BRRF1, BSLF2/BMLF1, BZLF1, BRLF1 and BMLF1 showed pan-cellular or clearly nuclear localization, whereas BALF1 and BCRF1 were absolutely distributed in the cytoplasm. Besides, all the packaging related protein (BFLF1, BFRF4 and
BGRF1/BDRF1) showed pan-cytoplasmic or pan-cellular localization, which is consistent with the compartment where the viral packaging takes place.

EBV is the first known human tumor virus to play an essential role in the induction of a broad spectrum of human lymphoid and epithelial malignancies [23-26], yet the fundamental mechanism of how EBV contributes to cancer remain unknown. Unlike other herpesviruses, the development of EBV-related tumorous diseases is relevant with the latent cycle, by virtue of the immune system is incompetent to monitor latently infected cells. It's shown that EBV can encode some viral oncoproteins that involved in EBV tumorigenicity (including EBNA1, EBNA2, LMP1, LMP2, EBNA3A, EBNA3C, BARF0, BALF1, RPMS1, BARF1 and BNLF1) [27-38], which are associated with Burkitt's lymphoma (EBNA1, LMP2A and BARF0), Hodgkin's disease, nasopharyngeal carcinoma and NK/T-cell lymphoma (EBNA1, LMP1, LMP2A and LMP2B), gastric carcinomas (BARF1), post-transplant lymphoproliferative disorders and AIDS-related lymphomas (EBNA1, EBNA3A, LMP1, LMP2A and LMP2B). It's well known the subcellular localization plays a critical role in the function execution of a specific protein, and therefore we speculated the subcellular localization of these mentioned EBV proteins might take some potential roles in the EBV-related lymphoid and epithelial malignancies, e.g. the subcytoplasmic localization of LMP1 may be crucial for it to lead to changes that is connected with B-cell activation, including B-cell fusion, increase of CD23, CD39, CD40, CD44 expression and apoptosis-restraining effects [39, 40]. Furthermore, this localization may also important for LMP1 to promote oncogenesis and transformation of primary rodent fibroblasts and to impede differentiation of a squamous carcinoma cell line [41]. However, the exact pathological roles in EBV-related malignancies are not fully elucidated, this need further in-depth study.

In conclusion, this study on the construction of a library of expression clones for the EBV proteome, we believe, will be a remarkably essential work in producing highly valuable platform for further studies of the viral life cycle and mechanistic pathogenesis in the future. Additionally, it will also be applicable for screening the possible viral proteins or host cellular factors that may interact with viral proteins.

\section{MATERIALS AND METHODS}

\section{Cell culture}

COS-7 cells, incubated at $37^{\circ} \mathrm{C}$ in a humidified $5 \% \mathrm{CO} 2$ incubator, were grown in Dulbecco's modified MEM (DMEM, Gibco-BRL) supplemented with 10\% fetal bovine serum (FBS; Gibco-BRL), $2 \mathrm{mM} \mathrm{L-glutamine,} \mathrm{and}$ $50 \mathrm{U} / \mathrm{ml}$ penicillin $\mathrm{G}$ and $50 \mu \mathrm{g} / \mathrm{ml}$ streptomycin. 


\section{Cloning of EBV genes}

The enzymes used for cloning programs were purchased from Thermo Scientific except DNA polymerase KOD-Plus-Neo from TOYOBO and T4 DNA Ligase from Takara. The 81 ORFs of EBV from the NCBI entries, including the start methionine, were amplified by PCR from the BAC DNA of B95-8 strain of EBV (174-kb BAC) except LF1, LF2 and LF3 from the BAC DNA of Akata strain of EBV (AK-BAC) [4], using specific primers with suitable overhanging restriction enzyme motifs (contain HindIII and BamHI sites unless otherwise specified). Due to EBV genome contains high GC, the annealing temperature for PCR reaction is generally high. EYFP has been widely employed as a reporter to visualize EYFP-tagged proteins in live cells. Therefore, the amplified DNA products were digested with HindIII and BamHI and inserted into the multicloning site of pEYFP-C1 (Clontech, BD Biosciences) in frame with an EYFP tag at the C terminus, which is digested with appropriate restriction enzymes, with the aim to yield corresponding EYFP fusion protein to allow direct observation of the subcellular localization of each protein. Furthermore, some representative proteins from each category (BFRF3 and BMRF1 from nuclear localization, BSLF1 and BGLF1 from cytoplasmic localization and BGLF2 and BSRF1 from pan-cellular localization) were also subcloned into pCMV-Flag-N1 (Beyotime Biotechnology) in frame with a Flag tag at the $\mathrm{N}$ terminus. All constructs described above were verified by plasmid PCR, restriction analysis and full-length DNA sequencing, and all primers used in this research are available upon request.

\section{Plasmid transfection and fluorescence microscopy}

To test the subcellular localization of EBV proteins in live cells, plasmid transfection and fluorescence microscopy assays were performed as described in our previous studies [42-46]. Briefly, COS-7 cells were plated onto 12 well plates (Corning, USA) and cultured in DMEM with $10 \%$ FBS overnight to reach the confluency $60-80 \%$ before transfection. The next day, monolayer cells were transfected with $1.5 \mu \mathrm{g}$ of assigned plasmid DNA mixed with TurboFect Transfection Reagent (Thermo Scientific) as per the manufacturer's instructions. After transfection for $24 \mathrm{~h}$, the live cells were beard for fluorescence microscopy. To make the data more convincing, the subcellular localizations of some representative proteins fused with Flag tag from each category were detected by IFA, using anti-Flag monoclonal antibody (mAb) (ABmart) and fluorescein isothiocyanate (FITC)-conjugated goat anti-mouse IgG (Sigma-Aldrich), as described in previous studies [47]. In the same observation, each transfection was carried out for at least two times. Data shown were from one illustrative experiment. Fluorescences were analyzed using a Zeiss Axiovert $200 \mathrm{M}$ inverted fluorescence microscope (Carl Zeiss, Germany), equipped with a halogen lamp (100 HAL, $12 \mathrm{~V}, 100$ Watt) for transmitted light microscopy and an objective LD "Plan-Neofluar" with $40 \times / 0.6$ Corr M27 $(\mathrm{D}=0-1.5)$ lens $(\mathrm{WD}=3.3 \mathrm{~mm}$ when $\mathrm{D}=0$ and $\mathrm{WD}=2.5 \mathrm{~mm}$ when $\mathrm{D}=1.5$ ). The YFP (EX BP 500/20, BS FT 515, EM BP 535/30), FITC (EX BP 475/40, BS FT 500, EM BP 530/50) and DAPI (EX G 365, BS FT 395, EM BP 445/50) filtersets were used to detect EYFP labelled proteins, FITC labelled proteins and nuclear DNA labelled with Hoechst, respectively. Transmitted and fluorescence light images were captured under a digital camera (Axiocam; Carl Zeiss), with Zeiss AxioVision Rel. 4.8 software for controlling the image recording, microscope stage and image merge. Microscopic settings were kept constant for comparisons among different samples. All the pictures were taken under a magnification of $400 \times$. Classification of subcellular localization of the proteins was determined by three researchers independently, and categorization was discussed until consensus was reached. Each picture represents most of the cells with similar subcellular localization. Light-translucent photomicrographs are introduced to show cellular morphology. Cells were counterstained with Hoechst to visualize the nuclear DNA. Fluorescent images of EYFP fusion proteins and FITC labelled protein were presented in pseudocolor green and genuine color green, respectively, and merged with Hoechst using Zeiss AxioVision Rel. 4.8 software. All scale bars indicate $10 \mu \mathrm{m}$, and images were processed using Adobe Photoshop.

\section{Author contributions}

Conceived and designed the experiments: MSC and MLL. Performed the experiments and analyzed the data: MSC, ZML, TC, PW, XMZ, YFW, ZX, SJ, JLH, DXC, TP, GDH and MLL. Wrote the paper: MSC and MLL. All authors contributed to and have approved the final manuscript.

\section{ACKNOWLEDGMENTS}

We thank Dr. Teru Kanda for the generous gift of 174-kb BAC and AK-BAC.

\section{CONFLICTS OF INTEREST}

The authors declare no conflicts of interest.

\section{GRANT SUPPORT}

This work was supported by grants from the National Natural Science Foundation of China (81772179, 31400150, 31200120 and 31370204); the Natural Science 
Foundation of Guangdong Province (2015A030313473); the Training Program for Outstanding Young Teachers in Universities of Guangdong Province (YQ2015132); the Medical Scientific Research Foundation of Guangdong Province, China (A2017055 and B2012165); the Science and Technology Plan Projects of Guangzhou City, China (201607010088); the Scientific Research Projects in Colleges and Universities of Guangzhou (1201430024, 1201610025 and 1201610024); Innovation and entrepreneurship training program in colleges and universities in Guangzhou (2017224104); HighLevel Universities Academic Backbone Development Program of Guangzhou Medical University; the Thousand Hundred Ten Projects of Guangzhou Medical University, Guangdong; Guangdong Undergraduate Training Programs of Science \& Technology Innovation (Guangdong Climb Plan: pdjh2017b0419); National, Provincial and School Level Training Programs of Innovation and Entrepreneurship for Undergraduates in Guangzhou Medical University (2016A002 and XS201609).

\section{REFERENCES}

1. Young LS, Murray PG. Epstein-Barr virus and oncogenesis: from latent genes to tumours. Oncogene. 2003; 22:5108-5121.

2. Samanta M, Iwakiri D, Kanda T, Imaizumi T, Takada K. EB virus-encoded RNAs are recognized by RIG-I and activate signaling to induce type I IFN. EMBO J. 2006; 25:4207-4214.

3. Huang T, Ji Y, Hu D, Chen B, Zhang H, Li C, Chen G, Luo X, Zheng XW, Lin X. SNHG8 is identified as a key regulator of Epstein-Barr virus(EBV)-associated gastric cancer by an integrative analysis of lncRNA and mRNA expression. Oncotarget. 2016; 7:80990-81002. https//doi. org/10.18632/oncotarget.13167.

4. Kanda T, Shibata S, Saito S, Murata T, Isomura H, Yoshiyama H, Takada K, Tsurumi T. Unexpected instability of family of repeats (FR), the critical cis-acting sequence required for EBV latent infection, in EBV-BAC systems. PLoS One. 2011; 6:e27758.

5. Tarbouriech N, Buisson M, Geoui T, Daenke S, Cusack S, Burmeister WP. Structural genomics of the Epstein-Barr virus. Acta Crystallogr D Biol Crystallogr. 2006; 62:1276-1285.

6. Salsman J, Zimmerman N, Chen T, Domagala M, Frappier L. Genome-wide screen of three herpesviruses for protein subcellular localization and alteration of PML nuclear bodies. PLoS Pathog. 2008; 4:e1000100.

7. Lin Z, Wang X, Strong MJ, Concha M, Baddoo M, Xu G, Baribault C, Fewell C, Hulme W, Hedges D, Taylor $\mathrm{CM}$, Flemington EK. Whole-genome sequencing of the Akata and Mutu Epstein-Barr virus strains. J Virol. 2013; 87:1172-1182.
8. Johannsen E, Luftig M, Chase MR, Weicksel S, CahirMcFarland E, Illanes D, Sarracino D, Kieff E. Proteins of purified Epstein-Barr virus. Proc Natl Acad Sci U S A. 2004; 101:16286-16291.

9. Fries KL, Sculley TB, Webster-Cyriaque J, Rajadurai P, Sadler RH, Raab-Traub N. Identification of a novel protein encoded by the BamHI A region of the Epstein-Barr virus. J Virol. 1997; 71:2765-2771.

10. Shannon-Lowe C, Adland E, Bell AI, Delecluse HJ, Rickinson AB, Rowe M. Features distinguishing EpsteinBarr virus infections of epithelial cells and B cells: viral genome expression, genome maintenance, and genome amplification. J Virol. 2009; 83:7749-7760.

11. Cai X, Schafer A, Lu S, Bilello JP, Desrosiers RC, Edwards R, Raab-Traub N, Cullen BR. Epstein-Barr virus microRNAs are evolutionarily conserved and differentially expressed. PLoS Pathog. 2006; 2:e23.

12. Oudejans JJ, van den Brule AJ, Jiwa NM, de Bruin PC, Ossenkoppele GJ, van der Valk P, Walboomers JM, Meijer CJ. BHRF1, the Epstein-Barr virus (EBV) homologue of the BCL-2 protooncogene, is transcribed in EBV-associated B-cell lymphomas and in reactive lymphocytes. Blood. 1995; 86:1893-1902.

13. Laux G, Perricaudet M, Farrell PJ. A spliced EpsteinBarr virus gene expressed in immortalized lymphocytes is created by circularization of the linear viral genome. EMBO J. 1988; 7:769-774.

14. Bodescot M, Perricaudet M. Clustered alternative splice sites in Epstein-Barr virus RNAs. Nucleic Acids Res. 1987; 15:5887.

15. Simpson JC, Neubrand VE, Wiemann S, Pepperkok R. Illuminating the human genome. Histochem Cell Biol. 2001; 115:23-29.

16. Huh WK, Falvo JV, Gerke LC, Carroll AS, Howson RW, Weissman JS, O'Shea EK. Global analysis of protein localization in budding yeast. Nature. 2003; 425:686-691.

17. Simpson JC, Wellenreuther R, Poustka A, Pepperkok R, Wiemann S. Systematic subcellular localization of novel proteins identified by large-scale cDNA sequencing. EMBO Rep. 2000; 1:287-292.

18. Sander G, Konrad A, Thurau M, Wies E, Leubert R, Kremmer E, Dinkel H, Schulz T, Neipel F, Sturzl M. Intracellular localization map of human herpesvirus 8 proteins. J Virol. 2008; 82:1908-1922.

19. Duarte M, Wang L, Calderwood MA, Adelmant G, Ohashi M, Roecklein-Canfield J, Marto JA, Hill DE, Deng H, Johannsen E. An RS motif within the Epstein-Barr virus BLRF2 tegument protein is phosphorylated by SRPK2 and is important for viral replication. PLoS One. 2013; 8:e53512.

20. Chiu YF, Sugden B, Chang PJ, Chen LW, Lin YJ, Lan YC, Lai CH, Liou JY, Liu ST, Hung CH. Characterization and intracellular trafficking of Epstein-Barr virus BBLF1, 
a protein involved in virion maturation. J Virol. 2012; 86:9647-9655.

21. Su MT, Liu IH, Wu CW, Chang SM, Tsai CH, Yang PW, Chuang YC, Lee CP, Chen MR. Uracil DNA glycosylase BKRF3 contributes to Epstein-Barr virus DNA replication through physical interactions with proteins in viral DNA replication complex. J Virol. 2014; 88:8883-8899.

22. Chen Y, Ciustea M, Ricciardi RP. Processivity factor of KSHV contains a nuclear localization signal and binding domains for transporting viral DNA polymerase into the nucleus. Virology. 2005; 340:183-191.

23. Young LS, Rickinson AB. Epstein-Barr virus: 40 years on. Nat Rev Cancer. 2004; 4:757-768.

24. Zur Hausen H, Schulte-Holthausen H. Presence of EB virus nucleic acid homology in a "virus-free" line of Burkitt tumour cells. Nature. 1970; 227:245-248.

25. Epstein MA. Recent studies with EB virus. Yale J Biol Med. 1975; 48:431-437.

26. Li QX, Young LS, Niedobitek G, Dawson CW, Birkenbach M, Wang F, Rickinson AB. Epstein-Barr virus infection and replication in a human epithelial cell system. Nature. 1992; 356:347-350.

27. Sbih-Lammali F, Djennaoui D, Belaoui H, Bouguermouh A, Decaussin G, Ooka T. Transcriptional expression of Epstein-Barr virus genes and proto-oncogenes in north African nasopharyngeal carcinoma. J Med Virol. 1996; 49:7-14.

28. Rowe M, Rowe DT, Gregory CD, Young LS, Farrell PJ, Rupani H, Rickinson AB. Differences in B cell growth phenotype reflect novel patterns of Epstein-Barr virus latent gene expression in Burkitt's lymphoma cells. EMBO J. 1987; 6:2743-2751.

29. Cesarman E, Mesri EA. Virus-associated lymphomas. Curr Opin Oncol. 1999; 11:322-332.

30. Niedobitek G, Young LS, Herbst H. Epstein-Barr virus infection and the pathogenesis of malignant lymphomas. Cancer Surv. 1997; 30:143-162.

31. Cohen JI. Epstein-Barr virus infection. N Engl J Med. 2000; 343:481-492.

32. Cabras G, Decaussin G, Zeng Y, Djennaoui D, Melouli H, Broully P, Bouguermouh AM, Ooka T. Epstein-Barr virus encoded BALF1 gene is transcribed in Burkitt's lymphoma cell lines and in nasopharyngeal carcinoma's biopsies. J Clin Virol. 2005; 34:26-34.

33. Al-Mozaini M, Bodelon G, Karstegl CE, Jin B, Al-Ahdal M, Farrell PJ. Epstein-Barr virus BART gene expression. J Gen Virol. 2009; 90:307-316.

34. Smith PR, de Jesus O, Turner D, Hollyoake M, Karstegl CE, Griffin BE, Karran L, Wang Y, Hayward SD, Farrell PJ. Structure and coding content of CST (BART) family RNAs of Epstein-Barr virus. J Virol. 2000; 74:3082-3092.

35. zur Hausen A, Brink AA, Craanen ME, Middeldorp JM, Meijer CJ, van den Brule AJ. Unique transcription pattern of Epstein-Barr virus (EBV) in EBV-carrying gastric adenocarcinomas: expression of the transforming BARF1 gene. Cancer Res. 2000; 60:2745-2748.

36. Masucci MG. Epstein-Barr virus oncogenesis and the ubiquitin-proteasome system. Oncogene. 2004; 23:2107-2115.

37. Wilson JB, Weinberg W, Johnson R, Yuspa S, Levine AJ. Expression of the BNLF-1 oncogene of Epstein-Barr virus in the skin of transgenic mice induces hyperplasia and aberrant expression of keratin 6. Cell. 1990; 61:1315-1327.

38. Tsao SW, Tsang CM, To KF, Lo KW. The role of EpsteinBarr virus in epithelial malignancies. J Pathol. 2015; 235:323-333.

39. Kulwichit W, Edwards RH, Davenport EM, Baskar JF, Godfrey V, Raab-Traub N. Expression of the Epstein-Barr virus latent membrane protein 1 induces B cell lymphoma in transgenic mice. Proc Natl Acad Sci U S A. 1998; 95:11963-11968.

40. Laherty CD, Hu HM, Opipari AW, Wang F, Dixit VM. The Epstein-Barr virus LMP1 gene product induces A20 zinc finger protein expression by activating nuclear factor kappa B. J Biol Chem. 1992; 267:24157-24160.

41. Dawson CW, Rickinson AB, Young LS. Epstein-Barr virus latent membrane protein inhibits human epithelial cell differentiation. Nature. 1990; 344:777-780.

42. Cai MS, Jiang S, Zeng ZC, Li XW, Mo CC, Yang YJ, Chen CK, Xie PP, Bian Y, Wang JL, Huang JL, Chen DX, Peng T, Li ML. Probing the nuclear import signal and nuclear transport molecular determinants of PRV ICP22. Cell Biosci. 2016; 6:3.

43. Li ML, Jiang S, Mo CC, Zeng ZC, Li XW, Chen CK, Yang YJ, Wang JL, Huang JL, Chen DX, Peng T, Cai MS. Identification of molecular determinants for the nuclear import of pseudorabies virus UL31. Arch Biochem Biophys. 2015; 587:12-17.

44. Cai MS, Jiang S, Li XW, Zeng ZC, Li ML. Characterization of the nuclear import mechanisms of HSV-1 UL31. Biol Chem. 2016; 397:555-561.

45. Cai M, Chen D, Zeng Z, Yang H, Jiang S, Li X, Mai J, Peng T, Li M. Characterization of the nuclear import signal of herpes simplex virus 1 UL31. Arch Virol. 2016; 161:2379-2385.

46. Cai MS, Huang ZB, Liao ZM, Chen T, Wang P, Jiang S, Chen DX, Peng T, Bian Y, Hong GD, Yang H, Zeng ZC, Li XW, Li ML. Characterization of the subcellular localization and nuclear import molecular mechanisms of herpes simplex virus 1 UL2. Biol Chem. 2017; 398:509-517.

47. Li M, Cui W, Mo C, Wang J, Zhao Z, Cai M. Cloning, expression, purification, antiserum preparation and its characteristics of the truncated UL6 protein of herpes simplex virus 1. Mol Biol Rep. 2014; 41:5997-6002.

48. Wang WH, Kuo CW, Chang LK, Hung CC, Chang TH, Liu ST. Assembly of Epstein-Barr virus capsid in promyelocytic leukemia nuclear bodies. J Virol. 2015; 89:8922-8931. 
49. Buck M, Burgess A, Stirzaker R, Krauer K, Sculley T. Epstein-Barr virus nuclear antigen $3 \mathrm{~A}$ contains six nuclearlocalization signals. J Gen Virol. 2006; 87:2879-2884.

50. Marschall M, Leser U, Seibl R, Wolf H. Identification of proteins encoded by Epstein-Barr virus trans-activator genes. J Virol. 1989; 63:938-942.

51. Chen H, Smith P, Ambinder RF, Hayward SD. Expression of Epstein-Barr virus BamHI-A rightward transcripts in latently infected B cells from peripheral blood. Blood. 1999; 93:3026-3032.

52. Medina-Palazon C, Gruffat H, Mure F, Filhol O, VingtdeuxDidier V, Drobecq H, Cochet C, Sergeant N, Sergeant A, Manet E. Protein kinase CK2 phosphorylation of EB2 regulates its function in the production of Epstein-Barr virus infectious viral particles. J Virol. 2007; 81:11850-11860.

53. Semmes OJ, Chen L, Sarisky RT, Gao Z, Zhong L, Hayward SD. Mta has properties of an RNA export protein and increases cytoplasmic accumulation of Epstein-Barr virus replication gene mRNA. J Virol. 1998; 72:9526-9534.

54. Gonnella R, Farina A, Santarelli R, Raffa S, Feederle R, Bei R, Granato M, Modesti A, Frati L, Delecluse HJ, Torrisi MR, Angeloni A, Faggioni A. Characterization and intracellular localization of the Epstein-Barr virus protein BFLF2: interactions with BFRF1 and with the nuclear lamina. J Virol. 2005; 79:3713-3727.

55. Kitamura R, Sekimoto T, Ito S, Harada S, Yamagata H, Masai H, Yoneda Y, Yanagi K. Nuclear import of EpsteinBarr virus nuclear antigen 1 mediated by NPI-1 (Importin alpha5) is up- and down-regulated by phosphorylation of the nuclear localization signal for which Lys379 and Arg380 are essential. J Virol. 2006; 80:1979-1991.

56. Covarrubias S, Richner JM, Clyde K, Lee YJ, Glaunsinger BA. Host shutoff is a conserved phenotype of gammaherpesvirus infection and is orchestrated exclusively from the cytoplasm. J Virol. 2009; 83:9554-9566.

57. Park R, El-Guindy A, Heston L, Lin SF, Yu KP, Nagy M, Borah S, Delecluse HJ, Steitz J, Miller G. Nuclear translocation and regulation of intranuclear distribution of cytoplasmic poly(A)-binding protein are distinct processes mediated by two Epstein Barr virus proteins. PLoS One. 2014; 9:e92593.

58. Segouffin-Cariou C, Farjot G, Sergeant A, Gruffat H. Characterization of the Epstein-Barr virus BRRF1 gene, located between early genes BZLF1 and BRLF1. J Gen Virol. 2000; 81:1791-1799.

59. Kusano S, Raab-Traub N. An Epstein-Barr virus protein interacts with Notch. J Virol. 2001; 75:384-395.

60. Kienzle N, Buck M, Greco S, Krauer K, Sculley TB. Epstein-Barr virus-encoded RK-BARF0 protein expression. J Virol. 1999; 73:8902-8906.

61. Henson BW, Perkins EM, Cothran JE, Desai P. Selfassembly of Epstein-Barr virus capsids. J Virol. 2009; 83:3877-3890.
62. Li R, Wang L, Liao G, Guzzo CM, Matunis MJ, Zhu H, Hayward SD. SUMO binding by the Epstein-Barr virus protein kinase BGLF4 is crucial for BGLF4 function. $\mathrm{J}$ Virol. 2012; 86:5412-5421.

63. Chang CW, Lee CP, Huang YH, Yang PW, Wang JT, Chen MR. Epstein-Barr virus protein kinase BGLF4 targets the nucleus through interaction with nucleoporins. J Virol. 2012; 86:8072-8085.

64. Cox MA, Leahy J, Hardwick JM. An enhancer within the divergent promoter of Epstein-Barr virus responds synergistically to the R and Z transactivators. J Virol. 1990; 64:313-321.

65. Heineman T, Gong M, Sample J, Kieff E. Identification of the Epstein-Barr virus gp85 gene. J Virol. 1988; 62:1101-1107.

66. Gong M, Kieff E. Intracellular trafficking of two major Epstein-Barr virus glycoproteins, gp350/220 and gp110. J Virol. 1990; 64:1507-1516.

67. Liao G, Huang J, Fixman ED, Hayward SD. The EpsteinBarr virus replication protein BBLF2/3 provides an origintethering function through interaction with the zinc finger DNA binding protein ZBRK1 and the KAP-1 corepressor. J Virol. 2005; 79:245-256.

68. Meckes DG Jr, Menaker NF, Raab-Traub N. EpsteinBarr virus LMP1 modulates lipid raft microdomains and the vimentin cytoskeleton for signal transduction and transformation. J Virol. 2013; 87:1301-1311.

69. Rovedo M, Longnecker R. Epstein-Barr virus latent membrane protein 2B (LMP2B) modulates LMP2A activity. J Virol. 2007; 81:84-94.

70. Lynch DT, Zimmerman JS, Rowe DT. Epstein-Barr virus latent membrane protein 2B (LMP2B) co-localizes with LMP2A in perinuclear regions in transiently transfected cells. J Gen Virol. 2002; 83:1025-1035.

71. Xiao J, Palefsky JM, Herrera R, Tugizov SM. Characterization of the Epstein-Barr virus glycoprotein BMRF-2. Virology. 2007; 359:382-396.

72. Loesing JB, Di Fiore S, Ritter K, Fischer R, Kleines M. Epstein-Barr virus BDLF2-BMRF2 complex affects cellular morphology. J Gen Virol. 2009; 90:1440-1449.

73. Bellows DS, Howell M, Pearson C, Hazlewood SA, Hardwick JM. Epstein-Barr virus BALF1 is a BCL-2-like antagonist of the herpesvirus antiapoptotic BCL-2 proteins. J Virol. 2002; 76:2469-2479.

74. Gong M, Ooka T, Matsuo T, Kieff E. Epstein-Barr virus glycoprotein homologous to herpes simplex virus gB. J Virol. 1987; 61:499-508.

75. Haan KM, Lee SK, Longnecker R. Different functional domains in the cytoplasmic tail of glycoprotein B are involved in Epstein-Barr virus-induced membrane fusion. Virology. 2001; 290:106-114.

76. Paulsen SJ, Rosenkilde MM, Eugen-Olsen J, Kledal TN. Epstein-Barr virus-encoded BILF1 is a constitutively active G protein-coupled receptor. J Virol. 2005; 79:536-546. 
77. Zuo J, Currin A, Griffin BD, Shannon-Lowe C, Thomas WA, Ressing ME, Wiertz EJ, Rowe M. The EpsteinBarr virus G-protein-coupled receptor contributes to immune evasion by targeting MHC class I molecules for degradation. PLoS Pathog. 2009; 5:e1000255.

78. Kaptein SJ, Jungscheleger-Russell J, Martinez-Martinez P, Beisser PS, Lavreysen H, Vanheel A, De Baets MH, Bruggeman CA, Vink C, Losen M. Generation of polyclonal antibodies directed against $\mathrm{G}$ protein-coupled receptors using electroporation-aided DNA immunization. J Pharmacol Toxicol Methods. 2008; 58:27-31.

79. de Turenne-Tessier M, Jolicoeur P, Middeldorp JM, Ooka T. Expression and analysis of the Epstein-Barr virus BARF1encoded protein from a tetracycline-regulatable adenovirus system. Virus Res. 2005; 109:9-18.

80. Horst D, van Leeuwen D, Croft NP, Garstka MA, Hislop $\mathrm{AD}$, Kremmer E, Rickinson AB, Wiertz EJ, Ressing ME. Specific targeting of the EBV lytic phase protein BNLF2a to the transporter associated with antigen processing results in impairment of HLA class I-restricted antigen presentation. J Immunol. 2009; 182:2313-2324.

81. Liao G, Wu FY, Hayward SD. Interaction with the Epstein-Barr virus helicase targets Zta to DNA replication compartments. J Virol. 2001; 75:8792-8802.

82. Heilmann AM, Calderwood MA, Johannsen E. Epstein-Barr virus LF2 protein regulates viral replication by altering Rta subcellular localization. J Virol. 2010; 84:9920-9931.

83. Nolan LA, Morgan AJ. The Epstein-Barr virus open reading frame BDLF3 codes for a 100-150 kDa glycoprotein. J Gen Virol. 1995; 76:1381-1392.
84. Lu CC, Huang HT, Wang JT, Slupphaug G, Li TK, Wu MC, Chen YC, Lee CP, Chen MR. Characterization of the uracilDNA glycosylase activity of Epstein-Barr virus BKRF3 and its role in lytic viral DNA replication. J Virol. 2007; 81:1195-1208.

85. Khanim F, Dawson C, Meseda CA, Dawson J, Mackett M, Young LS. BHRF1, a viral homologue of the Bcl-2 oncogene, is conserved at both the sequence and functional level in different Epstein-Barr virus isolates. J Gen Virol. 1997; 78:2987-2999.

86. Hickish T, Robertson D, Clarke P, Hill M, di Stefano F, Clarke C, Cunningham D. Ultrastructural localization of BHRF1: an Epstein-Barr virus gene product which has homology with bcl-2. Cancer Res. 1994; 54:2808-2811.

87. Lake CM, Hutt-Fletcher LM. The Epstein-Barr virus BFRF1 and BFLF2 proteins interact and coexpression alters their cellular localization. Virology. 2004; 320:99-106.

88. Lee CP, Liu PT, Kung HN, Su MT, Chua HH, Chang YH, Chang CW, Tsai CH, Liu FT, Chen MR. The ESCRT machinery is recruited by the viral BFRF1 protein to the nucleus-associated membrane for the maturation of EpsteinBarr virus. PLoS Pathog. 2012; 8:e1002904.

89. Chen MR, Hsu TY, Lin SW, Chen JY, Yang CS. Cloning and characterization of cDNA clones corresponding to transcripts from the BamHI G region of the Epstein-Barr virus genome and expression of BGLF2. J Gen Virol. 1991; 72:3047-3055. 